\title{
Endülüs Emevî Halifesi II. Hakem'in İlmî Kişiliği ve İlim Hayatına Sağladığı Katkılar*
}

\author{
Doç. Dr. Saim YILMAZ** \\ Furkan ERBAŞ ${ }^{* * *}$
}

Atıf / @)- Yılmaz, S.- Erbaş, F. (2017). Endülüs Emevî Halifesi II. Hakem'in İlmî Kişiliği ve İlim Hayatına Sağladığı Katkılar, Çukurova Üniversitesi Ilahiyat Fakültesi Dergisi, 17 (1), 157-185.

Öz- Endülüs Emevîleri'nde ilmî faaliyetler alanındaki en parlak devir, II. Hakem döneminde yaşanmıştır. Kendisi de âlim olan ve "Bilge Halife" olarak isimlendirilen II. Hakem, ülkesindeki ilmî faaliyetlerin artması için büyük bir gayret içerisinde olmuştur. Onun hiçbir ayırım yapmaksızın dönemindeki âlimlere kucak açması ve onlara tanıdığı geniş imkanlar, başkent Kurtuba'nın âlimlerin toplandığı önemli bir ilim merkezi haline gelmesini sağlamıştır. Aynı zamanda dünyanın dört bir tarafından toplanan kitaplarla, Medinetüzzehrâ saray kütüphanesi İslam dünyasının üç büyük kütüphanesinden biri haline getirilmiştir. Fakir çocuklara ücretsiz eğitim veren okullar açılarak ülkede okuryazarlık oranında ciddi bir artış sağlanmıştır. İi kısımdan meydana gelen bu makalede öncelikle II. Hakem'in ilmî kişiliği, ardından ülkesindeki ilim hayatına sağladığı katkılar ele alınacaktır.

Anahtar sözcükler- Endülüs Emevîleri, Hakem b. Abdurrahmân, Kurtuba Medresesi, Medinetüzzehra Saray Kütüphanesi

\section{$\S \S \S$}

Makalenin geliş tarihi: 22.12.2016; Yayına kabul tarihi: 19.06.2017

* Bu makale, "Endülüs Emevî Halifesi Hakem b. Abdurrahmân ve Dönemi” isimli yüksek lisans tezinden yararlanılarak üretilmiştir.

** Sakarya Üniversitesi İlahiyat Fakültesi İslam Tarihi Anabilim Dalı, eposta: saimy@sakarya.edu.tr

*** Sakarya Üniversitesi Sosyal Bilimler Enstitüsü İslam Tarihi Anabilim Dalı Yüksek Lisans Öğrencisi, eposta: furkan.erbas@igdir.edu.tr 


\section{Giriş}

Hakem b. Abdurrahmân'ın (350-366/961-976) yaklaşık on altı yıl süren halifelik dönemi, Endülüs Emevîleri'nin "altın çağı" olarak kabul edilen ve yaklaşık yüzyıl süren yükseliş döneminin (300-399/912-1009) ortasına tesadüf eder. Bu dönemin ilk elli yılını kapsayan babası III. Abdurrahmân (300-350/912-961) devrinde sağlanan siyasî ve askerî alanlardaki yükseliş ve istikrar dönemini; II. Hakem'in halifeliği döneminde yaşanan ilim, kültür ve medeniyet sahalarındaki parlak devir takip eder. Bu yüzden kaynaklar onun siyasî ve askerî başarılarından daha çok ilim, kültür ve medeniyet alanlarında yaptığı katkılardan söz eder. Nitekim onun döneminde Endülüs Emevîleri'nin başkenti Kurtuba, İslam dünyasındaki üç büyük ilim merkezinden biri haline gelmiştir.

"Bilge Halife" olarak isimlendirilen II. Hakem'in ilmî kişiliğini ve ülkesindeki ilim hayatına sağladığı katkıları ele almayı hedefleyen bu makale, iki kısımdan meydana gelmektedir. Birinci kısımda Endülüs Emevîleri'ne ilim alanında en parlak devri yaşatan ve âlim sıfatıyla tanınan II. Hakem'in ilmî kişiliği ele alınacaktır. Onun ülkesindeki ilim hayatına sağladığı katkıları ele alan ikinci kısım üç alt başlık altında incelenecektir. Öncelikle onun Kurtuba medresesinde, sarayda veya herhangi bir başka görevde istihdam ettiği veya eser telif etmeye teşvik ettiği âlimlerden Tabakat kitaplarından tespit edebildiğimiz kadarıyla örnekler sunularak, Kurtuba'nın canlı bir ilim merkezi haline gelmesindeki katkısı tespite çalışılacaktır. Ardından Medinetüzzehrâ Saray kütüphanesinin İslam dünyasındaki üç büyük kütüphaneden biri haline gelmesini sağlayan kitap koleksiyonu ve bunun için ortaya koyduğu gayret incelenecektir. Son olarak toplumda eğitim ve öğretimi yaygınlaştırmak adına yapmış olduğu düzenlemeler ve onun bu ilmî faaliyetlerinin topluma yansıması ortaya konacaktır.

\section{I. İImî Kişiliği}

Her idareci ülkesindeki ilmî faaliyetleri ilerletmek adına az veya çok bir takım düzenlemelerde bulunur. Çoğu zaman bu düzenlemeleri, söz konusu alana dışarıdan kanun ve emirlerle yön veren bir idarecinin icraatları şeklinde değerlendirmek mümkündür. Ancak II. Hakem'in bu alana olan ilgisini ve yaptığı düzenlemeleri, olaya dışarıdan yön veren herhangi bir idarecinin icraatları gibi ele almak yeterli ve doğru bir yaklaşım olmayacaktır. Onun halifelik öncesi ve halifelik sonrası hayatı bir bütün olarak incelendiğinde öncelikli uğraş alanının ilmî faaliyetler olduğu görülür. 
II. Hakem'in hayatını anlatan kaynakların vurguladığı en başta gelen özelliği "âlim ve dindar" kişiliğidir. Çocuk yaşta veliaht tayin edilen II. Hakem'in, babası III. Abdurrahmân tarafından özel olarak yetiştirildiği muhakkaktır. Nahiv âlimi Ebü'l-Velîd Hişâm b. Velîd el-Gâfikî (ö. 317/929), ${ }^{1}$ Osman b. Nasr b. Abdillâh el-Mushafî (ö. 325/937)2 ile nahiv ve mantık âlimi Muhammed b. İsmâil el-Hakîm (ö. 331/943) onun eğitim ve öğretimi ile ilgilenmeleri için özel olarak görevlendirilmiş hocalardandı. ${ }^{3}$ Çocukluk ve gençlik yıllarını ilim meclislerinde geçiren II. Hakem, pek çok sahada dönemin önde gelen âlimlerinden dersler aldı. Hadis, fıkıh, tarih, dil ve neseb âlimi Kâsım b. Esbağ elBeyyânî (ö. 340/951), ${ }^{4}$ III. Abdurrahmân zamanında Tuleytula'da kadılık yapmış olan muhaddis Ebû Ömer Ahmed b. Duhaym (ö. 338/950), ${ }^{5}$ muhaddis ve fakih Muhammed b. Muhammed b. Abdüsselâm el-Huşenî (ö. 333/945), ${ }^{6}$ Sa'd (veya Sa'îd) b. Câbir el-Kelâ‘î (ö. 325/937), ${ }^{7}$ muhaddis Ebû Yahya Zekeriyyâ b. Hattâb (ö. 337/949) ${ }^{8}$ ve Muhammed b. Mervân b. el-Gaşşâ el-Batalyevsî onun ders aldığı âlimlerden bazılarıydı. ${ }^{9}$ Ayrıca hadis, fıkıh, dil ve şiir âlimi

1 Abdullah b. Muhammed b. Faradî, Târîhu ulemâi'l-Endelüs (nşr. Beşşâr Avvâd), III, Tûnus 2008, II, 217-218.

2 İbnü'l-Faradî, Târîhu ulemâi'l-Endelüs, I, 397.

3 Muhammed b. Abdillâh b. Ebbâr, et-Tekmile li kitâbi's-sıla (thk. Abdûsselâm Mihrâs), I-IV, Beyrut 1995, I, 226. Ayrıca bk. İbnü'l-Faradî, Târîhu ulemâi'l-Endelüs, II, 72; Ebü'l-Kâsım Sâid b. Ahmed b. Sâid el-Endelüsî, Kitâbu tabakâti'l-ümem (nşr. P. Louis Cheikho), Beyrut 1912, s. 65.

4 Hayatı hakkında bilgi için bk. İbnü'l-Faradî, Târîhu ulemâi'l-Endelüs, I, 467-469; Mehmet Görmez, "Kâsım b. Esbağ", DIA, XXIV (İstanbul 2001), s. 540-541.

5 Hayatı hakkında bilgi için bk. İbnü'l-Faradî, Târîhu ulemâi'l-Endelüs, I, 78-79.

6 Hayatı hakkında bilgi için bk. İbnü'l-Faradî, Târîhu ulemâi'l-Endelüs, II, 74; Ebû Abdillâh Muhammed b. Ebî Nasr Fütûh (Fettûh) b. Abdillâh el-Humeydî, Cezvetü'lmuktebis (nşr. Muhammed Beşşâr Avvâd), Tûnus 2008, s. 57-58.

7 Hayatı hakkında bilgi için bk. İbnü'l-Faradî, Târîhu ulemâi'l-Endelüs, I, 234-235; Humeydî, Cezvetü'l-muktebis, s. 330; Ahmed b. Yahyâ b. Dabbî, Bugyetü'lmültemis fî târîhi ricâli ehli'l-Endelüs (nşr. İbrâhim el-Ebyârî), I-II, Kahire-Beyrut 1989, II, 17; Muhammed b. Ahmed ez-Zehebî, Târîhu'I-Islâm ve vefeyâtu'l-meşâhîr ve'l-a'lâm (Sene:321-330) (nşr. Ömer Abdüsselâm Tedmürî), Beyrut 1989, XXIV, 171-172.

8 Hayatı hakkında bilgi için bk. İbnü'l-Faradî, Târîhu ulemâi'I-Endelüs, I, 211-212.

9 Karşılaştırmalı olarak bk. İbnü'l-Ebbâr, et-Tekmile li kitâbi's-sıla, I, 226; Zehebî, Siyeru a'lâmi'n-nübelâ' (nşr. Şuayb el-Arnâut), I-XXV, Beyrut 1981-1982; VIII, 269; a.mlf, Târîhu'l-Islâm, XXVI, 358; Ahmed b. Muhammed el-Makkarî, Nefhu't-tîb min ğusni'l-Endelüsi'r-Râtib (thk. İhsân Abbâs), I-VIII, Beyrut 1988, I, 395. 
hocası Sâbit b. Kâsım b. Sâbit b. Hazm'dan (ö. 352/963) ${ }^{10}$ "ed-Delâil fi Garîbi'l-Hadîs" isimli kitap için icazeti bulunmaktaydı. ${ }^{11}$

Çocukluk ve gençlik yıllarında dönemin en seçkin hocalarından İslami ilimlerde iyi bir eğitim alan II. Hakem'in, ilerleyen yıllarda belli ilim dallarında daha da uzmanlaştığı bildirilmektedir. Fıkıh, ensâb ve tarih ilimleri onun ilgi duyduğu ve derinleştiği sahaların başında gelmekteydi. İbnü'l-Hatîb'in (ö. 776/1374-1375) ifadeleriyle o, mezhepleri ve aralarındaki görüş ayrılıklarını bilen bir fakihti. Neseb ilminde en önde gelenlerdendi. Çok geniş tarih bilgisine sahipti. Kitap aşığıydı ve kitap toplamayı çok severdi. Rical ilminde bir âlimi diğerinden, bir nesildekini diğer nesildekinden ayırabilecek temyiz gücüne sahipti. Bu alana özel bir ilgisi vardı ve bu yüzden bu alanda imam kabul edilirdi. ${ }^{12}$ İbnü'l-Hatîb'in anlatımına benzer ifadeleri döneme en yakın tarihçi İbn Hayyân (ö. 469/1076) ${ }^{13}$ başta olmak üzere II. Hakem'in hayatı hakkında bilgi veren kaynakların neredeyse tamamında bulmak mümkündür. ${ }^{14}$

II. Hakem çocuk yaşta veliaht tayin edilmiş olmasına rağmen babası III. Abdurrahmân'ın uzun süre hayatta kalması sebebiyle çok geç yaşta halife olabilmiştir. Geçen bu uzun sürenin onun ilimle daha fazla meşgul olmasını sağladığını düşünmek mümkündür. Nitekim İbnü’l-Ebbâr'ın (ö. 658/1260) bildirdiğine göre 0 , kütüphanesinde bulunan kitapların neredeyse tamamını okumuş ve incelemiştir. Baş tarafına, sonuna veya ekler ilave etmek suretiyle okuduğu her kitaba kendi el yazısıyla şerhler düşerdi. Bu şerhlerde kitap mü-

10 Detaylı bilgi için bk. İbrâhîm b. Alî b. Ferhûn, ed-Dîbâcu'l-müzheb fî ma'rifeti âyâni ulemâi'l-mezheb (nşr. Muhammed el-Ahmedî Ebu'n-nûr), I-II, Kahire 1972, II, 14748. İbn Ferhûn, Sâbit b. Kâsım'ın 302 yılında vefat ettiğini bildirmektedir. Bu bilgi yanlış olmalıdır. Zira kendisinden icâzet alan Halife II. Hakem 302 yılında doğmuştur. Nitekim İbnü'l-Faradî, Sâbit b. Kâsım'ın 352 yılında vefat ettiğini kaydetmektedir. Bk. İbnü'l-Faradî, Târîhu ulemâi'l-Endelüs, I, 155.

11 Karşılaştırmalı olarak bk. İbnü'l-Ebbâr, et-Tekmile li kitâbi's-sıla, I, 226; Zehebî, Siyeru a'lâmi'n-nübelâ', VIII, 269; a.mlf, Târîhu'l-Islâm, XXVI, 358; Makkarî, Nefhu't-tîb, I, 395.

12 Muhammed b. Abdillâh b. Hatîb, A'mâlu'l-a'lâm fî men bûyi'a kable'l-ihtilâm min mulûki'l-İslâm (nşr. Lêvi-Provençal), Beyrut 1956, s. 41; a. mlf., el-Ihhâta fi ahbâri Gırnâta (nşr. Muhammed Abdullah İnân), I-IV, Kahire 1974, I, 478. Ayrıca bk. Mehmet Özdemir, Endülüs Müslümanları (Siyasî Tarih), Ankara 2016, s. 143.

13 İbnü'l-Ebbâr, Kitâbu'l-hulleti's-siyerâ', I, 201.

14 Müellifi meçhul, Zikru bilâdi'l-Endülüs (nşr. Luis Molina), Madrid 1983, s. 169; Alî b. Muhammed b. el-Esîr, el-Kâmil fi't-târîh (thk. Ebi'l-Fidâ Abdullah el-Kâdî), I-XI, Beyrut, 1987, VIII, 677; Ebü'l-Fidâ İsmâîl b. Alî, el-Muhtasar fî ahbâri'l-beşer (nşr. Matbaatu'I Hüseyniyye el-Mısriyye), I-IV, Kahire 1286/1869, II, 117; İsmâîl b. Ömer b. Kesîr, el-Bidâye ve'n-nihâye (nşr. Abdullah b. Abdülmuhsîn et-Türkî), I-XXI, Riyad 1419/1998, XV, 371. 
ellifinin nesebi, doğum ve vefat tarihleri ile müellifi tanıtıcı diğer bilgileri kaydeder; hatta bu kitaptan rivayette bulunan ve bu kitap hakkında görüş belirten ravilerin nesebleri hakkında da bilgiler verirdi. Endülüslü âlimler güvenilir kabul ettikleri II. Hakem'in başka yerde bulunmayan bu bilgilerinden istifade ederek eserlerinde ondan alıntılar yaparlardı. ${ }^{15}$ Nitekim Târîhu ulemâi'l-Endelüs isimli eserin müellifi İbnü'l-Faradî (ö. 403/1013), muhaddis Ebû Yahyâ Zekeriyyâ b. Hattâb hakkındaki bir bilgiyi II. Hakem'in şerhinden okuduğunu nakletmektedir. ${ }^{16}$ Hatta İbnü'l-Faradî'den iki buçuk asır sonra yaşamış olan İbnü'l-Ebbâr, II. Hakem'in şerh yazdığı eserlerden kendisine de bir cüz ulaştığını ve bundan çokça faydalandığını bildirmektedir. ${ }^{17}$

Makkarî'nin (1041/1632) Nefhu't-tîb adlı eserinde verilen dolaylı bir bilgiden Halife II. Hakem'in sadece mevcut eserleri okumak, incelemek ve şerh etmekle kalmadığı bizzat kitap telif ettiği anlaşılmaktadır. Makkarî, doğudan Endülüs'e gelen Ali evladına mensup kişiler hakkında verdiği bilgiler kısmında Haşim b. Hüseyin hakkında aktardıklarını Halife II. Hakem'in Ensâbu'ttâlibiyyîne ve'l-aleviyyîne'l-kâdimîne ilâ'l-Mağrib isimli eserine dayandırmaktadır. ${ }^{18}$ Tespit edebildiğimiz kadarıyla II. Hakem'in telif ettiği bu eser günümüze ulaşmamıştır. Diğer taraftan Endülüs'ün siyasî tarihi hakkında bir eser yazmış olan Muhammed İmamüddin, II. Hakem'in İspanya tarihi üzerine de bir eser kaleme aldığını ancak bu eserin günümüze ulaşmadığını bildirmektedir. ${ }^{19} \mathrm{Ne}$ var ki incelediğimiz kaynaklarda böyle bir bilgiye tesadüf edemediğimizi belirtmemiz gerekir.

Dönemindeki ilim adamlarının güvenilir âlim olarak kabul ettikleri, şerh veya telif olarak yazmış olduklarından istifade ettikleri Halife II. Hakem, İbnü'lFaradî ve İbn Beşkuvâl'ın (ö. 578/1183) Endülüslü ilim adamlarını tanıtan biyografi eserlerinde yer almaz. İbnü'l-Ebbâr, bu iki müellifin eserlerinde, II. Hakem gibi büyük bir âlimin hayatına dair herhangi bir malumata yer vermemelerini haklı bir şekilde hayretle karşılar. ${ }^{20}$ Doğrusu söz konusu müelliflerin

15 İbnü'l-Ebbâr, et-Tekmile li kitâbi's-sıla, I, 227; a. mlf., Kitâbu'l-hulleti's-siyerâ' (nşr. Hüseyin Mû'nis), I-II, Kahire 1963, I, 202.

16 İbnü'l-Faradî, Târîhu ulemâi'l-Endelüs, I, 212.

17 İbnü'l-Ebbâr, et-Tekmile li kitâbi's-sıla, I, 227; a. mlf., Kitâbu'I-hulleti's-siyerâ', I, 202.

18 Makkarî, Nefhu't-tîb, III, 60.

19 S. Muhammed İmamüddin, Endülüs Siyasi Tarihi (trc. Yusuf Yazar), Ankara 1990, s. 210.

20 İbnü'l-Ebbâr, et-Tekmile li kitâbi's-sıla, I, 227. Ayrıca bk. Makkarî, Nefhu't-tîb, I, 395. 
bu tutumlarına, II. Hakem'i halife olarak kabul etmeleri sebebiyle eserlerine almamış olabilecekleri şeklinde bir izah getirmek dışında başka bir yorum yapmak mümkün gözükmez.

II. Hakem'in halife olmasıyla birlikte ilmî alandaki faaliyetleri tahmin edilenin aksine daha da artmıştır. Onun halife olmasından sonraki ilmî faaliyetlerine dair en net ifadeleri İbnü'l-Ebbâr'ın eserinde bulmak mümkündür. Onun çocukluğundan vefatına kadar ilimle meşgul olduğunu belirten müellif, ilimle meşgul olmayı krallığın dünyada sağlayacağı bütün lezzetlere tercih ettiğini ve bir an bile bu uğraşından vazgeçmediğinin önemle altını çizer. ${ }^{21}$ Halife oluncaya kadar sürekli kendi ilmî birikimini artırmaya çalışan II. Hakem, makalenin bundan sonraki kısmında genişçe ele alınacağı gibi halife olduktan sonra da sürekli ilim meclislerine katılarak, âlimleri himaye ederek ve büyük bir kitap koleksiyonu oluşturarak kendisiyle birlikte ülkesinin ve halkın bu alandaki seviyesini artırmak adına elinden gelen bütün gayreti ortaya koymuştur.

\section{II. İlim Hayatına Sağladığı Katkılar}

\section{1. Âlimleri Himayesi}

Endülüs Emevîleri, ilim, kültür ve medeniyet sahalarındaki en parlak dönemini II. Hakem'in halifeliği zamanında yaşamıştır. Babası III. Abdurrahmân'ın uzun süren halifeliği döneminde içeride ve dışarıda sağlamış olduğu sükûn ve istikrar, bu duruma zemin hazırlayan en önemli unsur olmuştur. Siyasî ve askerî alanda sağlanan bu huzur ortamı, âlim kişiliğiyle tanınan II. Hakem'in elinde devletin ilim, kültür ve medeniyet sahalarında büyük bir sıçrama yapmasının önünü açmıştır.

II. Hakem döneminde en fazla ilerlemenin kaydedildiği ilmî alandaki faaliyetlerin iki temel düstura dayandığını söylemek mümkündür. Bunlardan birincisi ilmin yeşereceği zemini hazırlamak; ikincisi ise bu faaliyetlerin toplum tarafından benimsenmesinde ön ayak olmaktır. İlmî alanda Endülüs Emevîleri'ne altın çağını yaşatan II. Hakem, bu işi kanun ve emirlerle tanzim etmek yerine ilmin yeşereceği zemini hazırlamak adına ilmin olmazsa olmaz iki unsurunu bir araya getirmenin gayreti içerisinde olmuştur. Bu iki aslî unsurdan biri olan âlimler, onun tarafından daima himaye görmüş ve teşvik edilmişlerdir. Bundan sonraki kısımda ele alınacağı gibi en az âlimler kadar ilgi gören diğer unsur kitaplar olmuştur. Bir taraftan ülkesindeki âlimleri kitap telif etmek için

21 İbnü'l-Ebbâr, et-Tekmile li kitâbi's-sıla, I, 226. Ayrıca bk. Makkarî, Nefhu't-tîb, I, 395. 
sürekli teşvik ederken, diğer taraftan da ülkesi dışında yazılan kitapları elde etmek için hiçbir fedakârlıktan kaçınmamıştır.

II. Hakem döneminde yaşamış âlimlerin biyografilerini konu alan tabakat kitapları üzerinde yapılacak hızlı bir tarama, onun âlimleri himaye etme hususundaki gayretlerine şahitlik edecek birçok veriye ulaşmak için yeterli olacaktır. İlme olan düşkünlüğü ile ün salmış olan II. Hakem alanında uzman birçok ilim adamını himaye ederek, ${ }^{22}$ onları Kurtuba medresesinde, Medinetüzzehrâ sarayında ve daha pek çok önemli görevlerde istihdam etmiştir. Bunlardan pek çoğunu eser telif etmeye teşvik ederken, kaleme aldıkları eserleri kendisine takdim eden âlimleri ise taltif etmeyi inmal etmemiştir. Kuşkusuz onun âlimlere gösterdiği bu yakın ilgi ve alaka pek çok âlimin Endülüs'e gelmesine ve pek çok yeni eserin telif edilmesine kapı aralamış ve buranın canlı bir ilim merkezine dönüşmesini sağlamıştır.

İbnü's-Saffâr diye bilinen Ebû Muhammed Abdullâh b. Muhammed b. Muğîs (ö. 352/963), Halife II. Hakem'in itibar gösterdiği Endülüs'ün meşhur şair ve ediplerindendi. II. Hakem 352 (963) yılında Hristiyan krallıklar üzerine sefere çıkarken İbnü's-Saffâr'a savaşta kendisine eşlik etmesi için haber gönderdi. Ancak İbnü's-Saffâr rahatsızlığı sebebiyle bu sefere gelemeyeceğini bildirdi. Bunun üzerine Halife II. Hakem, Ebû Bekir es-Sûlî'nin (ö. 335/946) ${ }^{23}$ Abbâsî halifelerinin şiirlerini bir araya getirdiği eserine benzeyen doğudaki ve Endülüs'teki Emevî halifelerinin şiirlerini derleyen bir kitap yazması halinde onun bu mazeretini kabul edeceğini bildirdi. İbnü's-Saffâr bu teklifi kabul edince II. Hakem sarayındaki nehire nâzır bir odayı rahat bir şekilde çalışabilmesi için ona tahsis etti. İbnü's-Saffâr'ın, bütün vaktini ayırarak kısa zamanda yazımını tamamladığı bu eser, henüz seferden dönmemiş olan II. Hakem'e Tuleytula'da iken ulaştırılmıştır. ${ }^{24}$

Arap dili ve edebiyatı alanında belki de II. Hakem'in en fazla ilgisine mazhar olan âlim, Ebû Ali el-Kâlî el-Bağdâdî (ö. 356/967) olmuştur. II. Hakem'in babası III. Abdurrahmân zamanında Bağdat'tan Endülüs'e davet edilen

22 Louis Bertrand, Ispanya Tarihi (trc. Galip Kemali Söylemezoğlu, Nurullah Ataç), İstanbul 1940, s. 53.

23 Türk asıllı tarihçi, edip ve aynı zamanda şair olan Ebû Bekir es-Sûlî'nin hayatı hakkında bilgi için bk. Abdülkerim Özaydın, "Sûlî, Ebû Bekir", DIA, XXXVII (İstanbul 2009), s. 492-493.

24 Humeydî, Cezvetü'l-muktebis, s. 363, 364; İbn Beşkuvâl, es-sıla (nşr. İbrâhim elEbyârî), I-III, Kahire 1990, I, 378; Dabbî, Bugyetü'l-mültemis, II, 431-432; Julian Ribera, el-Mektebâtu ve hevâtu'l-kutubi fî İspânyâ el-İslâmiyye (Arapça trc. Cemâl Muhammed Mihraz), I-II, Kahire 1958, I, 89. 
Ebû Ali, 330 (941) yılında Kurtuba'ya geldiğinde Halife III. Abdurrahmân ve veliaht II. Hakem tarafından büyük bir törenle karşılanmıştır. II. Hakem halife olduktan sonra da Ebû Ali el-Kâlî̀yi hiçbir zaman yanından ayırmamış; o daima sevip saydığı ve istifade ettiği âlimlerden birisi olmuştur. Kurtuba medresesinin yanı sıra Medinetüzzehrâ sarayında da dersler vermesi istenen Ebû Ali el-Kâlî, buralarda Arap tarihi, ensâb ilmi, Arap dili, şiiri ve edebiyatı gibi dersler okutmuştur. Arap dili ve edebiyatına dair meşhur "el-Emâlî" adlı eserini Endülüs'e geldikten sonra kaleme almıştır. Endülüs'te telif edilen ilk sözlük olma özelliğine sahip "el-Bâri' fîl-luga" isimli eserini ise Halife II. Hakem'in isteği doğrultusunda kaleme almış ve kendisine takdim etmiştir. ${ }^{25}$ Nitekim İbn Haldûn (ö. 808/1406), II. Hakem'in daima himaye ve desteklerini gören Ebû Ali el-Kâlî̀nin Endülüs ilim hayatına kazandırdıklarını ifade ederken "onun ilmi ve birikimleri Endülüs'e miras kalmıştır"26 demektedir.

Ebû Ali el-Kâlî, Endülüs'te Arap Edebiyatı alanında pek çok ilim adamı yetiştirmiş ve bunlar da Halife II. Hakem tarafından himaye edilmişlerdir. Dil ve edebiyat âlimi Muhammed b. Ebî'l-Hüseyin el-Fihrî (ö. 394/1003-1004), Ebû Alî el-Kâlî̀nin öğrencisi ve aynı zamanda kâtibiydi. Halife II. Hakem, Ebû Ali el-Kâlî'den, ünlü dil ve edebiyat âlimi Halîl b. Ahmed'in (ö. 175/791) meşhur sözlüğü Kitâbu'l-‘ayn gibi bir sözlük telif etmesini istediğinde onu da hocasına yardım etmek üzere görevlendirmiştir. Halife II. Hakem'in isteği üzerine Ebû Alî el-Kâlî tarafından telif edilen "el-Bâri' fî'l-luga" isimli bu eserin tertib edilerek temize çekilmesi görevi de Muhammed el-Fihrî ile Muhammed b. Ma'mer el-Ceyyânî’ye verilmiştir. ${ }^{27}$

Ensâb ve tarih ilimlerinin yanı sıra Arap dilinde de yetkin bir kimse olan Muhammed b. Ebân el-Lahmî (ö. 354/965), Ebû Alî el-Kâlî’nin öğrencilerinden olup II. Hakem'in kendisine itibar gösterdiği âlimlerdendi. Şurta kadılığı görevinde bulunan Muhammed b. Ebân'ın pek çok telif kitabı bulunmaktaydı. ${ }^{28}$

25 Ebû Ali el-Kâlî hakkında bilgi için bk. Ebû Ali İsmâîl b. el-Kâsım b. Ayzûn el-Kâlî elBağdâdî, el-Emâlî, (nşr. Dâru'l-kutubi'l-ilmiyye), I-IV, Beyrut ts. I, 11, 15-16, 17; İbn Haldûn, Kitâbu'l'Íber ve divânü'l-mübtede' ve'I-haber, (nşr. Halîl Şehâde), I-VII Beyrut 2001, IV, 187; Makkarî, Nefhu't-tîb, I, 386; Ebû Sâlih, "Cühûdü'l-Hakem", Mecelle Dirâsât Endelüsiyye, VI, 38; Hüseyin Elmalı, "Kâlî", DIA, XXIV (İstanbul 2001), s. 259-260. İbn Haldûn, el-'iber, IV, 187.

27 Humeydî, Cezvetü'l-muktebis, s. 78-79; Dabbî, Bugyetü'l-mültemis, I, 99; Süleyman Tülücü, "el-Bâri", DIA, V (İstanbul 1992), s. 73-74.

28 İbnü'l-Faradî, Târîhu ulemâi'l-Endelüs, II, 91; Zehebî, Tarihu'I-Islâm, XXVI, 111. 
Mutarrif b. Îsâ el-Gassânî (ö.356/966) Halife II. Hakem döneminde yaşamış, Arap dili ve edebiyatı alanında önde gelen alimlerdendi. Bu alanda pek çok kıymetli eseri bulunan Mutarrif b. Îsâ, II. Hakem tarafından İlbîre kâdıIığına tayin edilmiştir. ${ }^{29}$ Araştırmacılardan Abdullah İnân onun Ahbâru kûretu İlbîre adlı eserini II. Hakem'e takdim ettiğini belirtmekteyse de ${ }^{30}$ biz kaynaklarda bunu teyit eden bir bilgiye rastlayamadık.

Arap dili ve edebiyat alimi ve aynı zamanda dönemin önde gelen fıkıh ve kelam alimlerinden olan Muhammed b. Yahyâ er-Rebâhî (ö. 358/969), II. Hakem'in babası III. Abdurrahmân döneminde halifenin oğlu Mugîre'nin eğitimi ile görevlendirilmişti. II. Hakem halife olduktan sonra Muhammed b. Yahyâ er-Rebâhî’yi çeşitli divanlarda görevlendirmek suretiyle onun idarede daha iyi bir konum elde etmesine imkan sağlamıştı. ${ }^{31}$

Edebiyat alimi ve şair Ahmed b. Muhammed b. Ferec el-Ceyyânî (ö. 366/976), Halife II. Hakem'in isteği doğrultusunda İbn Dâvûd el-İsfahânî'nin (ö. 297/910) eseri “Kitâbu'z-zühre" nin benzeri "Kitâbu'l-Hadâik” isimli bir şiir antolojisi derleyerek bu eseri halifeye takdim etmiştir. Kitabını 200 bölüme ayıran İbn Ferec, her bölümde sadece Endülüslü şairlerden seçtiği 200 beyit kaydetmiştir. ${ }^{32}$

Arap dili ve edebiyatı âlimi Ebû Bekir Muhammed b. Hasen ezZübeydî (ö. 379/989), memleketi İşbîliye'den bizzat Halife II. Hakem tarafından Kurtuba'ya davet edilmiştir. Burada halifenin oğlu veliaht II. Hişâm'ın (366-399/976-1009) özel hocası olarak görevlendirilmiştir. Halife II. Hakem'in en yakın dostlarından biri haline gelen Ebû Bekir ez-Zübeydî, daha sonra memleketi İşbîliye'ye dönmek istemişse de buna izin verilmemiştir. Halife II. Hakem'in oğlu II. Hişâm döneminde Kurtuba'da kadılık ve şurta görevlerinde bulunan Ebû Bekir ez-Zübeydî, en son kendi isteği üzerine memleketi İşbîliye'ye kadı tayin edilmiş ve bu görevde iken vefat etmiştir. Kurtuba'da bulun-

29 Detaylı bilgi için bk. İbnü'l-Faradî, Târîhu ulemâi'l-Endelüs, II, 173; Kâdî lyâz b. Mûsâ b. İyâz, Tertîbu'l-medârik ve takrîbu'l-mesâlik (thk. Sa'îd Ahmed A'râb), I-VIII, Rabat 1403/1982, VII, 19; Ebü'l-Fazl Celâlüddîn Abdurrahmân b. Ebî Bekr esSüyûtî, Buğyetü'l-vu'ât fî tabakati'l-lugaviyyîn ve'n-nuhâ (thk. Muhammed Ebü'lFazl İbrâhim), I-II, Beyrut 1399/1979, II, 289.

30 Muhammed Abdullâh 'İnân, Devletü'I-İslâm fi'l-Endelüs, I-II, Kahire 1417/1997, I, 505.

31 Muhammed b. Hasen ez-Zübeydî, Tabakâtu'n-nahviyyîn ve'l-lügaviyyîn (nşr. Muhammed Ebû'l-Fazl İbrâhim), Kahire 1954, s. 314; İbnü'l-Faradî, Târîhu ulemâi'lEndelüs, II, 93-94.

32 Dabbî, Bugyetü'l-mültemis, I, 194; Mehmet Yavuz, “íbn Ferec el-Ceyyânî”, DiA, XIX (İstanbul 1999), s. 491. Ayrıca bk. İbn Beşkuvâl, es-sıla, I, 30. 
duğu süre içerisinde birçok Arap dili ve edebiyatı âlimi yetiştiren Ebû Bekir ezZübeydî, aynı zamanda bu alanda pek çok kıymetli eser de telif etmiştir. ${ }^{33}$ Bunlardan "Tabakâtu'n-nahviyyîn ve'l-lügaviyyîn" isimli eseri Halife II. Hakem'in isteği doğrultusunda kaleme almıştır. Bu eserin mukaddimesinde kaydettiğine göre II. Hakem, kendisinden başlangıçtan o güne kadar yaşamış olan nahiv, lugat ve edebiyat âlimlerinin doğum, ölüm, nesep, seyahat, mezhep bilgilerini ve ilimdeki derecelerini gösteren bir eser telif etmesini istemiştir. Bunun üzerine eseri telif etmeye başlayan Ebû Bekir ez-Zübeydî, bu süreçte Halife II. Hakem'den maddî-manevî büyük destek gördüğünü belirtir. ${ }^{34}$

Kudüs'ten 360'lı yıllarda Endülüs'e gelen Ebû Mervân Abdülmelik b. Muhammed, II. Hakem'in itibar gösterdiği ve himaye ettiği dil ve edebiyat âlimlerinden birisiydi. ${ }^{35}$

Dil ve edebiyata karşı büyük ilgi gösteren Halife II. Hakem'in emri doğrultusunda Endülüslü şairlerin hayatlarını anlatan ve şiirlerini konu alan başka eserlerin de telif edildiği ancak bunlardan bir kısmının günümüze ulaşmadığı anlaşılmaktadır. Nitekim II. Hakem döneminde Endülüslü şairlerin biyografilerini kaydeden birçok kitap vücuda getirildiğini zikreden İbn Hazm (ö. 456/1064), bunlardan "Ahbâru şu'arâi İlbîre" isimli bir kitabın on cüzlük bölümünü bizzat gördüğünü ifade etmektedir. ${ }^{36}$ Humeydî'nin (ö. 488/1095) bildirdiğine göre ise Halife II. Hakem'in emriyle Endülüslü şair İbn Abdirrabbih'e (ö. 328/940) ${ }^{37}$ ait şiirler bir araya toplanmıştır. Humeydî, kendi zamanına ulaşan bu eserin yirmi cüzünden fazlasını bizzat görmüş ve incelemiştir. ${ }^{38}$

Endülüslü tarihçi Ebû Abdullâh Muhammed b. Yûsuf el-Verrâk, "Mesâlikü Ifrîkıyâ ve memâlikühâ" isimli eserini II. Hakem'in isteği üzerine telif

33 Geniş bilgi için bk. Ebû Mervân Halef b. Hayyân, el-Muktebes min enbâi ehli'lEndelüs (nşr. Abdurrahmân Ali el-Haccî), Beyrut 1965, s. 133-34; Alî b. Mûsâ b. Saîd el-Mağribî, el-Muğrib fî hule'l-Mağrib (nşr. Şevkî Dayf), I-II, Kahire 1953-1955, I, 255-56; Makkarî, Nefhu't-tîb, IV, 7; Halit Zevalsiz, "Zübeydî, Ebû Bekir", DIA, XLIX (İstanbul 2013), s. 519-520.

Zübeydî, Tabakât, s. 17-18. Ayrıca bk. Zevalsiz, "Zübeydî, Ebû Bekir", s. 519-520.

35 İbnü'l-Faradî, Târîhu ulemâi'l-Endelüs, I, 365.

36 Makkarî, Nefhu't-tîb, III, 174.

37 Hakkında detaylı bilgi için bk. Humeydî, Cezvetü'l-muktebis, 151-154; Dabbî, Bugyetü'l-mültemis, I, 191-193

38 Humeydî, Cezvetü'l-muktebis, s. 151; Dabbî, Bugyetü'l-mültemis, I, 191. Ayrıca bk. Faruk Çiftçi, Endülüs'te Hilafet Dönemi Edebî Çevresi, (Yayımlanmamış Doktora Tezi), Atatürk Üniversitesi Sosyal Bilimler Enstitüsü, Erzurum 1999, s. 68-69. 
etmiştir. ${ }^{39}$ Aynı şekilde tarihçi İshâk b. Seleme, II. Hakem'in isteği üzerine yarımadadaki şehirler, kaleler, valiler, savaşlar, fakihler ve şairler ile ilgili bilgilerin yer aldığı bir Endülüs tarihi kaleme almıştı. ${ }^{40}$ Yine edebiyatçı ve tarihçi Îsâ b. Ahmed b. Muhammed el-Kinânî de (ö. 379/989) kaynaklarda adı zikredilmeyen bir tarih kitabını II. Hakem'ın isteği üzerine telif etmişti. ${ }^{41}$

Antakyalı kıraat âlimi Ebü'l-Hasen Ali b. Muhammed el-Antakî (ö. 377/987) Kurtuba'ya II. Hakem'in halifelik dönemine tesadüf eden 352 (963) yılında gelmiştir. Kaynaklar onun buraya gelmesi için Halife II. Hakem tarafından herhangi bir davetin yapılıp yapılmadığını zikretmezler. Ancak dönemin en önde gelen kıraat alimine Halife II. Hakem'in büyük bir itibar ve saygı gösterdiğinin önemle altını çizerler. ${ }^{42}$

Mâliki fakihlerin şeyhi kabul edilen İshâk b. İbrâhîm b. Meserre (ö. 354/965), II. Hakem'in beraber olduklarında istediği gibi oturmasına müsaade ettiği ve son derece saygı gösterdiği âlimlerden birisiydi. ${ }^{43}$

Mâlikî fakihi ve biyografi yazarı Ebû Abdullâh Muhammed b. Hâris elHuşenî (ö. 361/971) II. Hakem'in veliahtlığı sırasında Kurtuba'ya gelmişti. II. Hakem'in ona karşı veliahtlığı sırasında gösterdiği yakın ilgi halifeliği döneminde artarak devam etmiştir. Muhammed b. Hâris el-Huşenî, onun halifeliği döneminde Beccâne'de mirasla ilgili kadılık görevine ve Kurtuba'da şûra üyeliğine tayin edilmiştir. Muhammed b. Hâris el-Huşenî'nin başta meşhur eseri "Kudâtu Kurtuba" olmak üzere pek çok eserini II. Hakem için kaleme aldığı kaydedilmektedir. 44

39 Humeydî, Cezvetü'l-muktebis, s. 145; İbnü'l-Ebbâr, et-Tekmile li kitâbi's-sıla, I, 294; Makkarî, Nefhu't-tîb, III, 163.

40 İbnü’l-Faradî, Târîhu ulemâi'l-Endelüs, I, 126. Ayrıca bk. Humeydî, Cezvetü'lmuktebis, s. 237.

41 Ebû Abdullâh Muhammed b. Muhammed el-Merrâküşî, ez-Zeyl ve't-Tekmiletu likitâbi'l-vusûl ve's-sıla (nşr. İhsân Abbâs), I-VI, Tunus 2012, III, 408.

42 İbnü'l-Faradî, Târîhu ulemâi'l-Endelüs, I, 411-412; Zehebî, Tarihu'l-Islâm, XXVI, 613-614. Ayrıca bk. Sühâ Ba'yûn, İshâmu'I-ulemâi'l-müslimîn fi'l-ulûmi fî'l-Endelüs, Beyrut 2008, s. 89.

43 Zehebî, Siyeru a'lâmi'n-nübelâ', XVI, s. 79-80, 107-108.

44 Muhammed b. Hâris el-Huşenî, Kudâtu Kurtuba ve ulemâi lfrikiyye (thk. Seyyid İzzet Attâr), Kahire 1372/1953, neşredenin mukaddimesi, s. 7; İbnü'l-Faradî, Târîhu ulemâi'l-Endelüs, II, 147-148; Zehebî, Siyeru a'lâmi'n-nübelâ', XVI, 165-166; Ahmet Özel, "Huşenî, Muhammed b. Hâris", DIA, XVIII (İstanbul 1998), s. 421-422. 
Fakih Muhammed b. Abdullâh b. Seyyid (ö. 363/973-974), Halife II. Hakem için "el-Müstahrece" adlı eseri tasnif etmiştir. ${ }^{45}$ Endülüslü Mâlikî fakihi Utbî (ö. 255/869) tarafından kaleme alınan ve mezhep içerisinde şöhret bulan eserde, Mâlikî fakihlerin görüşleri derlenmiştir. ${ }^{46}$

Endülüslü fakihlerden Ahmed b. Abdülmelik b. Hâşim el-Işbîlî (ö. 401/1010) ve Ebû Bekr Muhammed b. Ubeydullâh el-Kureşî el-Mu'aytî (ö. 367/978), Halife II. Hakem'in teşvikiyle Mâlikî mezhebi imamı Mâlik b. Enes'in (ö. 179/795) görüşlerini "el-Istî́ab" adlı eserde toplayarak II. Hakem'e ithaf etmişlerdir. II. Hakem buna çok sevinmiş ve kendilerini kadılar şûrasına davet ederek oradakilerin kendisinden ilmî hususlarda faydalanmasını sağlamıştır. ${ }^{47}$

Mu'tezile mezhebine mensup akılcı görüşleriyle tanınan fakih ve dil alimi Ahmed b. Abdulvehhâb b. Yûnus (ö. 369/979), II. Hakem'in saraydaki ilim meclislerine katılan alimlerden birisiydi. ${ }^{48}$

Hadis alanında dönemin önde gelen muhaddislerinden Ebü'l-Kasım Hâlid b. Sa'd el-Kurtubî (ö. 352/963) Endülüslü hadis alimlerini anlatan bir ricâl kitabını II. Hakem'in talebi üzerine telif etmişti. Aslen Kurtubalı olan Hâlid b. Sa'd hakkında II. Hakem'in "Doğudakiler bize karşı Yahyâ b. Maîn (ö. 233/848) 49 ile övündüklerinde biz de onlara karşı Hâlid b. Sa'd ile övünürüz." dediği kaydedilmektedir. ${ }^{50}$

Muhaddis Muhammed b. Yahyâ b. Müferric (ö. 380/990), Halife II. Hakem'in kendisine itibar gösterdiği âlimlerdendi. Hadis ilminde ve özellikle hadis ricâli konusunda derin bilgi sahibi olan İbn Müferric'in fıkhü'l-hadîse ve Hasan-ı Basrî ile Zührî'nin görüşlerini derlediği kitapları başta olmak üzere tâbiîn fıkhına dair eserler telif etmiştir. Bu eserlerinden bir kısmını Halife II. Hakem'e takdim eden İbn Müferric, yine onun emriyle hocası Kāsım b. Asbağ'ın rivayetlerini "Müsned" adı altında bir araya toplamıştır. II. Hakem değer

45 İbnü'l-Faradî, Târîhu ulemâi'l-Endelüs, II, 99.

46 Eser hakkında detaylı bilgi için bk. Ali Hakan Çavuşoğlu, "Utbî, Muhammed b. Ahmed", DIA, XLII (İstanbul 2012), s. 238.

47 İbn Beşkuvâl, es-Sıla, I, 54.

48 İbnü'l-Faradî, Târîhu ulemâi'l-Endelüs, I, 93.

49 Hayatı hakkında bilgi için bk. Erdinç Ahatlı, "Yahyâ b. Maîn", DIA, XXXXIII (İstanbul 2013), s. 256-257.

50 İbnü'l-Faradî, Târîhu ulemâi'l-Endelüs, I, 189-191. 
verdiği bu âlimi sırasıyla İstece ve Reyyo şehirlerine kadı olarak tayin etmiştir. ${ }^{51}$

Muhaddis Ebû Osman Ya'îş b. Sa'îd b. Muhammed el-Verrâk (ö. 394/1003) "Müsned" adlı eserini Halife II. Hakem'in isteği doğrultusunda telif etmişti. ${ }^{52}$

İlimler arasında ayrım gözetmeyen II. Hakem, tıp ilmiyle uğraşan dönemin önde gelen alimlerine de destek olmuş; sarayda doktor olarak veya diğer hizmetlerde onlardan istifade etmiştir. Tabip, şâir ve dilci olan Muhammed b. Temlîh (ö.361/972), Halife III. Abdurrahmân döneminde itibar görmüş bilginlerdendi. Bu özelliğini II. Hakem nezdinde de sürdürmeye devam etmiştir. II. Hakem onu Kurtuba camiinin genişletilmesi ve bir takım ilaveler yapılması aşamasında denetim yapması için vazifelendirmişti. Tarihçi Sâid elEndelüsî (ö. 462/1070), Kurtuba camii mihrabı duvarında onun isminin altın varakla yazılmış olduğunu bildirmektedir. ${ }^{53}$ İbnü'l-Kinânî nisbesiyle ünlü Ebü’lVelîd Muhammed b. Hüseyin (ö 358'den sonra), II. Hakem ve babası tarafından himaye görmüş dönemin önde gelen tıp alimlerindendi. ${ }^{54}$ İyi bir mantıkçı ve filozof olan Ahmed b. Hakem b. Hafsûn (ö. 372/982), II. Hakem'in himayesi altına aldığı bilginlerdendi. Asıl mesleği tabiplik olan Ahmed b. Hakem, II. Hakem'in himayesi altına girdikten sonra bu mesleğini sarayda da devam ettirmiştir. ${ }^{55}$ Ebû Bekr Ahmed b. Câbir (ö. 366'dan sonra), II. Hakem ve oğlu II. Hişâm'ın himayesinde Kurtuba'da tabiplik yapmış deneyimli bir şahsiyetti. ${ }^{56}$ Aynı şekilde Ebû Abdülmelik es-Sakafî de Halife II. Hakem ve babası döne-

51 İbnü'l-Faradî, Târîhu ulemâi'l-Endelüs, II, 122-24; Humeydî, Cezvetü'l-muktebis, s. 61-62; Makkarî, Nefhu't-tîb, II, 218-219; H. Kamil Yaşaroğlu, "İbn Müferric", DiA, XX (İstanbul 1999), s. 215. Ayrıca bk. Ali b. Hasan İbn Asâkir, Târîhu medîneti Dımaşk (nşr. Ömer b. Garâme el-Amrî), I-LXXX, Beyrut 1415-1421/1995-2001, LI, 114-117; Dabbî, Bugyetü'l-mültemis, I, 69-70.

52 Dabbî, Bugyetü'l-mültemis, II, 691.

53 Ebû Dâvûd Süleymân b. Hassân b. Cülcül, Tabakâtu'l-etıbbâ ve'l-hukemâ (thk. Fuâd Seyyid), Beyrut 1985 s. 108-109; Sâid el-Endelüsî, Kitâbu tabakâti'l-ümem, s.80; Ahmed b. el-Kâsım b. Ebî Usaybia, Uyûnu'l-enbâ' fî tabakâti'l-etibbâ' (thk. Nizâr Rızâ), Beyrut 1965, s. 491.

54 İbn Cülcül, Tabakâtu'l-etıbbâ, s. 109; Sâid el-Endelüsî, Kitâbu tabakâti'l-ümem, s. 80; İbn Ebî Usaybia, Uyûnu'l-enbâ', s. 491.

55 İbn Cülcül, Tabakâtu'l-etıbbâ, s. 110; Sâid el-Endelüsî, Kitâbu tabakâti'l-ümem, s. 80; İbn Ebî Usaybia, Uyûnu'l-enbâ', s. 491.

56 İbn Cülcül, Tabakâtu'l-etıbbâ, s. 110; İbn Ebî Usaybia, Uyûnu’l-enbâ', s. 492. 
minde himaye görmüş bir tabip ve mühendisti. ${ }^{57}$ Tabiplerin pîri olarak kabul edilen Ebû Mûsâ Hârûn el-Eşûnî de II. Hakem'in ve babası III. Abdurrahmân'ın himayesinde bulunan şahsiyetlerdendi. ${ }^{58}$ II. Hakem'in yanında tabiplik görevini yerine getirenlerden birisi de Ebu'l-'Alâ b. Ebû Ca'fer Ahmed b. Hassân'dır. ${ }^{59}$ Ebû Abdullah en-Nedrûmî de aynı şekilde II. Hakem'in yanında tabiplik görevini deruhte etmiş bir zattı. ${ }^{60}$

Yunus b. Ahmed el-Harrânî'nin iki oğlu Ömer (ö. 351'den sonra) ve Ahmed (ö. 366'dan sonra) halife III. Abdurrahmân zamanında ilim tahsil etmek için Bağdat'a gitmişler ve burada kaldıkları on yıl süre zarfında ünlü Yunan filozofu ve tabibi Calinus'un (ö. 200) kitaplarını okumuşlardır. 351 (962) yılında Endülüs'e dönen bu iki kardeşi II. Hakem himayesi altına almış ve onlara tıp alanında çalışmalar yapmaları için destek olmuştur. ${ }^{61}$ Muhammed b. Âbdûn el-Cebelî de (ö. 361/972) 347 (958) yılında Mısır ve Basra'ya ilim tahsil etmek için gitmiştir. Buralarda tıp alanında tahsil görerek bu alanda temâyüz etmiştir. 360 (971) yılında Endülüs'e dönen Muhammed, II. Hakem tarafından himaye altına alınmış ve onun oğlu II. Hişâm zamanında da çalışmalarını sürdürmüştür. ${ }^{62}$

II. Hakem'in alimleri himaye etme konusunda gayri müslim ilim adamlarını da desteklemekten geri kalmadığı anlaşılmaktadır. ${ }^{63}$ Nitekim Yahudi şeriatı ve tarihi hakkında derin bilgiye sahip olan Yahudi bilginlerinden Hasdây b. İshâk, tıp alanında da temayüz etmiş bir kimseydi. Bu Yahudi alimi Halife II. Hakem'in hizmetinde bulunmaktaydı. ${ }^{64}$

57 İbn Cülcül, Tabakâtu'l-etıbbâ, s. 111; Sâid el-Endelüsî, Kitâbu tabakâti'l-ümem, s. 80; İbn Ebî Usaybia, Uyûnu'l-enbâ', s. 492.

58 İbn Cülcül, Tabakâtu'l-etıbbâ, s. 112; İbn Ebî Usaybia, Uyûnu’l-enbâ', s. 492.

59 Bilgi için bk. İbn Ebî Usaybia, Uyûnu'l-enbâ', s. 535.

60 Bilgi için bk. İbn Ebî Usaybia, Uyûnu'l-enbâ', s. 537.

61 İbn Cülcül, Tabakâtu'l-etıbbâ, s. 112-13; Sâid el-Endelüsî, Kitâbu tabakâti'l-ümem, s. 80,81 .

62 İbn Cülcül, Tabakâtu'l-etıbbâ, s. 115-16; Sâid el-Endelüsî, Kitâbu tabakâti'l-ümem, s. 81.

63 II. Hakem'in gayri müslim ilim adamlarına verdiği destek hakkında değerlendirme için bk. Reinhart Pieter Anne Dozy, Spanish Islam (Ingilizce trc. F. Griffin Stokes), London 1972, s. 455.

64 Sâid el-Endelüsî, Kitâbu tabakâti'l-ümem, s. 88-89; İbn Ebî Usaybia, Uyûnu'l-enbâ', s. 498; Abdülmecîd Na'naî, Târîhu'd-devleti'i-emeviyye fî Endülüs, Beyrut 1986, s. 411. 
II. Hakem döneminde matematik ve astronomi alanında da önemli ilim adamları yetişmiş ve bunlar da halifenin desteğine muhatap olmuşlardır. Endülüs'te bu bilim dallarının gelişmesinde büyük katkısı bulunan filozof, matematikçi ve astronomi bilgini Ebü'l-Kâsım Mesleme b. Ahmed el-Mecrîtî (ö. 398/1007) II. Hakem zamanında yaşamıştı. Onun usturlab, ticari aritmetik ve Harizmî tablolarının bir özeti hakkında telif ettiği eserler bu alanda özel bir öneme sahipti. Mesleme, Harizmî'nin Zic'inde önemli düzenlemeler yapmış ve Arin'in meridyenini değiştirmiştir. ${ }^{65}$ Levî-Provençal Hakem döneminde Mesleme'nin adıyla Endülüs'te bir medrese açıldığını belirtmekteyse de ${ }^{66}$ bu bilgiyi kaynaklardan teyit edemediğimizi belirtmemiz gerekir. Muhtemelen onun bu tespiti, Mecrîtînnin astronomi ve matematik alanlarında yetiştirmiş olduğu talebelerin kendinden sonraki dönemde bir ekol haline gelmesine işaret ediyor olmalıdır.

II. Hakem'in değer verdiği ve çalışmalarını desteklediği bu alanlardaki âlimlerden birisi de matematik, geometri ve kimya alanlarında âlim, nahivde de üstat bir kimse olan Abdullah b. Muhammed es-Sirrî'dir. ${ }^{67}$ Ebû Bekir Ahmed b. Muhammed b. Ahmed ise II. Hakem döneminde matematik, geometri ve astronomi alanlarında dersler veren alimlerden biriydi. 68

\section{Kitap Koleksiyonu: Saray Kütüphanesi}

Halife II. Hakem'in Endülüs'te ilmin gelişmesi için yaptığı en önemli katkılardan birisi de Medinetüzzehrâ sarayında büyük bir kütüphane oluşturmasıydı. "Kitap kurdu" olarak nitelenen II. Hakem, önceki kısımda ele alındığı gibi bir taraftan dönemindeki alimleri kitap telif etmeye yönlendirirken, diğer taraftan da Endülüs dışında yazılan kitapları elde etmek için büyük bir gayret içerisine girmiştir. Nitekim İbnü'l-Ebbâr, onun bu özelliğini dile getirirken İslam dünyasında kitap toplamak için Halife II. Hakem kadar gayret gösteren ikinci bir halifenin bulunmadığını ifade eder. ${ }^{69}$

65 Sâid el-Endelüsî, Kitâbu tabakâti'l-ümem, s. 69; Alî b. Yûsuf b. el-Kıftî, Ihbâru'lulemâ' bi ahbâri'l-hükemâ' (thk. İbrâhim Şemsüddîn), Beyrut 2005, s. 244; İbn Ebî Usaybia, Uyûnu'l-enbâ's. 482-483.

66 Lêvi-Provençal, Târîhu İspanya el-Islâmiyye mine'l-fethi ilâ sükûti'l-hilâfetî'lKurtubiyye (711-1031) (Arapça trc. Ali Abdürraûf el-Bembî ve dğr.), I-II, Kahire 2002, II, 441.

67 Sâid el-Endelüsî, Kitâbu tabakâti'l-ümem, s. 67-68; Ba'yûn, İshâm, s. 116.

68 Sâid el-Endelüsî, Kitâbu tabakâti'l-ümem, s. 68.

69 İbnü'l-Ebbâr, Kitâbu'l-hulleti's-siyerâ', I, 201.

ÇÜiFD, 2017, cilt: 17, sayı: 1, ss. 157-185 
Halife II. Hakem'in kitap toplama konusundaki çaba ve gayretleri, İslam dünyasındaki üç büyük kütüphaneden biri kabul edilen Medinetüzzehrâ Saray Kütüphanesinin oluşmasını sağlamıştır. Kalkaşendî'nin (ö. 821/1418) bildirdiğine göre İslâm dünyasında üç meşhur kütüphane mevcuttur. Bunlardan birincisi Abbâsîler'in Bağdat'ta kurmuş oldukları kütüphanedir. Sayılamayacak derecede çok kitap barındıran bu kütüphane, 656 (1258) yılındaki Moğol istilası sırasında yıkılmıştır. İkincisi Mısır'da içerisinde pek çok kıymetli eseri barındıran Fâtımîler'e ait kütüphanedir. Üçüncü kütüphane ise Endülüs Emevîleri'ne ait meşhur saray kütüphanesidir. ${ }^{70}$ Kalkaşendî, bu kütüphanenin II. Hakem dönemine ait olduğunu açık bir şekilde ifade etmez. Ancak İbn Haldûn, Endülüs saray kütüphanesinde en fazla kitabın II. Hakem döneminde toplandığını net bir şekilde belirtir. ${ }^{71}$

Kaynaklarda II. Hakem'in oluşturduğu kütüphane de 400.000 cilde yakın kitap bulunduğu, ${ }^{72}$ burada bulunan kitapların isimlerinin kaydedildiği katalogların ellişer yapraklık ${ }^{73}$ kırk dört ciltten oluştuğu bildirilmektedir. ${ }^{74} \mathrm{Bu}$ kütüphane, bulunduğu yer dar geldiği için taşınması gerektiğinde yeni yapılan bir binaya altı ay gibi bir süre zarfında ancak taşınabilmiştir. ${ }^{75}$

II. Hakem'in bu denli büyük bir kütüphane oluşturmasında seleflerinin bırakmış oldukları miras önemli bir yer tutmaktaydı. Endülüs Emevî sarayında, devletin kurucusu I. Abdurrahmân zamanında bir kütüphane oluşturulmuştu. Dördüncü Endülüs Emevî emiri II. Abdurrahmân (206-238/822-852) kitap biriktirmeye çok meraklı bir hükümdardı. O, Grekçe ve Farsça'dan Arapça'ya tercüme edilmiş eserleri toplamaları için özel memurlar görevlendirmişti. ${ }^{76}$ Beşinci Endülüs Emevî emiri olan I. Muhammed (238-273/852-886) zamanında saray kütüphanesi Kurtuba'daki en büyük kütüphanelerden biri haline gel-

70 Ahmed b. Alî el-Kalkaşendî, Subhu'l-a'şâ fî sınâ'ati'l-inşâ (nşr. Muhammed Abdürresûl İbrâhim), I-XIV, Kahire 1340/1922, I, 466-67.

71 İbn Haldûn, el-'iber, IV, 188; Makkarî, Nefhu't-tîb, I, 386.

72 Makkarî, Nefhu't-tîb, I, 395; Zikru bilâdi'l-Endelüs, s. 169. Bu rakamın 600.000 olduğu da söylenmiştir. bk. Hakkı Dursun Yıldız, "Endülüs Emevileri”, Doğuştan Günümüze Büyük Islam Tarihi, I-XV, İstanbul 1992, IV, 484.

73 Alî b. Ahmed b. Saîd b. Hazm, Cemheretu ensâbi'l-'Arab (nşr. Lêvi-Provençal), Mısır 1948, s. 92. Bu katalogların yirmi yapraktan meydana geldiği hakkında bk. İbn Haldûn, el-íber, IV, 187; İbn Saîd, el-Muğrib, I, 186.

74 İbn Hazm, Cemheretu ensâbi'l-'Arab, s. 92.

75 Makkarî, Nefhu't-tîb, I, 395; Ribera, el-Mektebât, I, 89.

76 Doğuştan Günümüze Büyük İslam Tarihi, IV, 482. 
mişti. ${ }^{77}$ II. Hakem'in babası III. Abdurrahmân'a Bizans İmparatoru VII. Konstantin'in (295-348/908-959) hediye ettiği kıymetli kitaplarla bu kütüphane daha da zenginleşmişti. ${ }^{78}$ Halife olduktan sonra seleflerinden devraldığı saray kütüphanesine iki önemli koleksiyonu birden ilave eden II. Hakem, mevcut kütüphanenin bir anda zenginleşmesini sağlamış oldu. Bu iki önemli koleksiyondan birisi kitap aşığı olan II. Hakem'in, çocukluğundan beri oluşturduğu kendi şahsî kütüphanesiydi. Diğer önemli koleksiyon ise babasından önce vefat eden kardeşi Abdullah'a ait olan ve onun vefatından sonra kendisine intikal etmiş bulunan kardeşinin özel kütüphanesiydi. ${ }^{79}$

II. Hakem'in Medinetüzzehrâ saray kütüphanesindeki kitap koleksiyonunu çoğaltma çabaları halifeliği boyunca devam etmiştir. Kitap elde etmek için hiçbir masraf ve külfetten kaçınmayan II. Hakem, Kahire, Dımaşk, Bağdat, Mekke, Medine, Kayrevan ve Horasan gibi ilim ve kültür merkezlerinde kitap satın almakla görevli temsilciler bulundurmaktaydı. Böylece çok yüksek meblağlara da olsa eski ve yeni kıymetli yazmaları temin edebiliyordu. ${ }^{80}$ Edebiyatçı ve lügatçi Muhammed b. Ebi'l Hüseyin el-Fihrî, Ceyyanlı Muhammed b. Ma'mer Bağdat'ta kitap toplamak ile görevli Muhammed b. Tarhân bunlardan sadece birkaçıydı. ${ }^{81} \mathrm{II}$. Hakem kitap toplama konusunda Endülüslü olmayan kimseleri de bu görevde istihdam etmiştir. Söz konusu görevlilerden Mısırı İbn Hayyân, Bağdatlı İbn Yakûb el-Kindî ve yine Bağdatlı Muhammed İbn Fercân'ı sayabiliriz. ${ }^{82}$

II. Hakem, ilim merkezlerinde bulundurduğu temsilciler vasıtasıyla sadece mevcut kitapları temin etmekle kalmaz, aynı zamanda müelliflerin yazmakta olduğu kitaplardan da haberdar olabilmekteydi. Ardından gönderdiği hediyelerle bu eserlerin ilk olarak kendisine takdim edilmesini sağlayabilmek-

77 'İnân, Devletü'l-Islâm, I, 504; Özdemir, Endülüs Müslümanlar (Siyasî Tarih), s. 143.

78 Makkarî, Nefhu't-tîb, I, 367; 'İnân, Devletü'-Islâm, I, 505.

79 İbnü'l-Ebbâr, Kitâbu'l-hulleti's-siyerâ', I, 201; a.mlf, et-Tekmile, I, 227; Na'naî, Târîhu'd-devleti'l-Emeviyye, s. 409; Lane-Poole Stanley, The Moors of Spain, London 1888, s. 155.

80 Karşılaştırmalı olarak bk. Muhammed b. Ahmed ez-Zehebî, Düvelü'l-Islâm (nşr. Hasan İsmâil Merve, Mahmûd el-Arnâût), I-II, Beyrut 1999, I, 334; İbn Haldûn, el'Íber, IV, 187-88; Makkarî, Nefhu't-tîb, I, 386; Mehmet Özdemir, "Hakem II", DIAA, XV (İstanbul 1997), s. 173-174.

81 Karşılaştırmalı olarak bk. Humeydî, Cezvetü'l-muktebis, s. 78-79; İbnü'l-Ebbâr, Kitâbu'I-hulleti's-siyerâ', I, 202; İmamüddin, Endülüs Siyasi Tarihi, s. 208; Ribera, el-Mektebât, I, 88.

82 Ribera, el-Mektebât, I, 88. 
teydi. ${ }^{83}$ Nitekim meşhur Emevî tarihçisi ve şair Ebu'l-Ferec el-İsfahânî'nin (ö. 356/967) "el-Eğânî" adlı meşhur eserini bitirmek üzere olduğunu öğrenince kendisine 1000 dinar göndererek eserin ilk nüshasını kendisine takdim etmesini istemiştir. Bunun üzerine II. Hakem'in isteğini geri çevirmeyen Ebu'l-Ferec el-İsfahânî, eserin yazımını tamamladıktan sonra ilk olarak bu eseri II. Hakem'e göndermiştir. Hatta Ebu'l-Ferec el-İsfahânînnin, bu kitaptan başka Benî Ümeyye'yi öven bir kasideyi ve Emevî ailesi mensuplarını tanıtan ve onların menkıbelerini anlatan bir eseri de II. Hakem için kaleme aldığı ve kendisine gönderdiği kaydedilmektedir. ${ }^{84}$ II. Hakem'in kendisiyle irtibata geçtiği âlimlerden biri de Mâlikî fakih Ebû Bekr Muhammed b. Abdullâh el-Ebherî (ö. 375/986) olmuştur. O, İmam Mâlik'in önde gelen talebelerinden Abdullâh İbn Abdilhakem el-Leysî̀nin (ö. 214/829) "el-Muhtasarü's-sağîr" adlı eserine yazmış olduğu şerhi, II. Hakem'in talebi doğrultusunda ilk olarak Endülüs'e göndermiştir. ${ }^{85}$ İbnü'l-Ebbâr'ın bildirdiğine göre II. Hakem, Mısırı Mâlikî fakihlerin önde gelenlerinden Ebu İshâk Muhammed b. Kâsım b. Şa'bân ve Ebu Ömer Muhammed b. Yûsuf b. Ya'kûb el-Kindî’ye de çeşitli hediyeler göndermiştir. ${ }^{86}$

Medinetüzzehra saray kütüphanesinde birçok memur çalışmaktaydı. İbn Haldûn oldukça kabiliyetli ve usta olarak nitelediği bu memurların istinsah, tasnif ve ciltleme işleriyle meşgul olduklarını belirtmektedir. ${ }^{87}$ Dışarıdan gelen kitaplar kütüphanedeki görevliler tarafından istinsah edilerek en güzel şekilde ciltlemeleri yapılmaktaydı. ${ }^{88}$ Ebü'l-Fazl Âbbâs b. Âmr el-Kinânî (ö.379/989), ${ }^{89}$ Ebû Yahya Zekeriyya b. Abdullah, ${ }^{90}$ Yûsuf el-Bellûtî ve Zafer el-Bağdâdî, ${ }^{91}$ Dilci Ebû Ca'fer Ahmed b. Sa'îd b. Makdes, ${ }^{92}$ kitap istinsah eden ve ciltleyen

83 Hüseyin Algül, İslam Tarihi, I-IV, İstanbul 1997, III, 473; Hasan İbrâhim Hasan, Siyasi-Dînî-Kültürel-Sosyal İslâm Tarihi (trc. İsmail Yiğit-Sadrettin Gümüş), I-VI, İstanbul 1992, IV, 87.

84 İbnü'l-Ebbâr, Kitâbu'l-hulleti's-siyerâ', I, 201-202; İbn Haldûn, el-'íber, IV, 188; Makkarî, Nefhu't-tîb, I, 386; Reinhart Dozy, el-Müslimûn fî Endelüs (Arapça trc: Hasan Habeşî), I-III, Kahire 1994, II, 67.

85 İbn Haldûn, el-'iber, IV, 188; Makkarî, Nefhu't-tîb, I, 386. İbnü'l-Ebbâr, Kitâbu'l-hulleti's-siyerâ', I, 201.

İbn Haldûn, el-íber, IV, 188.

Lêvi-Provençal Êvariste, el-Hadâratü'l-'Arabiyye fî İspanya (Arapça trc. Tâhir Ahmed Mekkî), Kahire 1414/1994, s. 89-90.

İbnü'l-Faradî, Târîhu ulemâi'l-Endelüs, I, 390.

İbnü'l-Ebbâr, et-Tekmile li kitâbi's-sıla, I, 264.

İbnü'l-Ebbâr, et-Tekmile li kitâbi's-sıla, I, 264.

İbnü'l-Faradî, Târîhu ulemâi'l-Endelüs, I, 96. 
görevlilerdendi. ${ }^{93}$ Kurtubalı meşhur edip, şair ve tarihçilerden biri olan Arîb b. Sa'd'da (ö.369/979-80) II. Hakem'in hizmetindeki kâtiplerindendi. ${ }^{94}$ Kütüphanede istihdam edilen görevliler arasında bayanlar da yer almaktaydı. Doksan dört yaşında vefat etmiş olan Fâtımâ bnt. Zekeriyyâ b. Abdullâh babası gibi II. Hakem'in kâtipliğini yapan deneyimli bir kimseydi. ${ }^{95}$ Yine bayanlardan II. Hakem'in kütüphanesinde kâtiplik görevinde bulunanlardan birisi de şâir, hattat ve dilci olan Kurtubalı Lübnâ (ö. 374/984) idi. ${ }^{96}$

Kütüphanenin kataloglarından Telid isimli bir genç sorumluydu. ${ }^{97}$ II. Hakem, kütüphanenin genel idaresini kardeşi Abdülazîz'e tevdi etmişti. Diğer kardeşi Münzir ise Kurtuba medresesinin idaresinden sorumlu idi. ${ }^{98}$

Bazı tarihçilerin "kitapların dar gelmeye başladığı kütüphane" olarak tanımladıkları II. Hakem'in büyük emeklerle oluşturduğu Medinetüzzehra saray kütüphanesinde ${ }^{99}$ bulunan kitapların pek çoğu kendisinden kısa bir süre sonra yok edilmiştir. Ne yazık ki bu kütüphanedeki kitapların çoğu oğlu II. Hişâm'ın halifeliği döneminde idareyi elinde bulunduran Hâcib Mansûr İbn Ebû Âmir tarafından bir kısmı satılmış ve geriye kalan kısmı ise yine onun teşvikleri ile Berberîler tarafından yağmalanmıştır. ${ }^{100}$

93 İmâmuddîn, Endülüs Siyasi Tarihi, s. 208; Ribera, el-Mektebât, I, 87. Ayrıca bk. Makkarî, Nefhu't-tîb, III, 111.

94 Watt W. Montgomery-Pierre Cachia, Endülüs Tarihi (trc. Cumhur Ersin Adıgüzel, Qiyas Şükürov), İstanbul 2011, s. 85; Mehmet Aykaç "Arîb b. Sa'd", DIA, III (İstanbul 1991) s. 359-360.

95 İbn Beşkuvâl, es-sıla, III, 994; İbnü'l-Ebbâr, et-Tekmile li kitâbi’s-sıla, I, 264; Ribera, el-Mektebât, I, 87.

96 İbn Beşkuvâl, es-sıla, III, 992; Ribera, el-Mektebât, I, 87.

97 İbnü'l-Ebbâr, et-Tekmile li kitâbi's-sıla, I, 190; Ribera, el-Mektebât, I, 87.

98 'İnân, Devletü'l-İslâm, I, 506; Halîl İbrâhîm Sâmirâî, Târîhu'l-Ârab ve hadâratuhum fi'l- Endelüs, Beyrut 2000, s. 191; Ba'yûn, İshâm, s. 80.

99 Zehebî, Siyeru a'lâmi'n-nübelâ', VIII, 269; Abdülhayy b. Ahmed b. İmâd, Şezerâtu'z-zeheb fî ahbâri men zeheb (nşr. Abdülkâdir el-Arnâût, Muhammed elArnâût), I-X, Beyrut 1989, IV, 352.

100 İbn Haldûn, el-'iber, IV, 188; Makkarî, Nefhu't-tîb, I, 386. 


\section{Toplumda Eğitim-Öğretim Faaliyetlerini Yaygınlaştırması}

Çocukluğundan beri ilmi faaliyetler içerisinde bulunan ve dönemin alimleri arasında kabul edilen II. Hakem, halife olduktan sonra kendisiyle birlikte devletinin ve halkının bu alandaki seviyesini artırmak adına elinden gelen bütün gayreti ortaya koymuştur. Onun dönemindeki alimleri himaye etmesi ve onları çeşitli alanlarda istihdam etmesinin yanı sıra, çeşitli bölgelerden getirttiği kitaplarla sarayında büyük bir kütüphane oluşturması devletin merkezi Kurtuba'nın önemli bir ilim merkezi haline gelmesini sağlamıştır. Bununla birlikte onun bu alandaki en büyük başarısı yapmış olduğu bu faaliyetlere halkın katıIımını sağlamış olmasıdır. Bu husustaki en açık tespit, II. Hakem'den kısa bir süre sonra yaşayan ve Tuleytula şehrinde kadılık görevinde bulunan Sâid elEndelüsî'ye aittir. Onun tespitlerine göre II. Hakem'in ilme karşı olan düşkünlüğü ve bu yönde yapmış olduğu çalışmalar, Endülüs halkına ilim öğrenme hususunda ilham kaynağı olmuştur. Halifenin bu çabalarını gören halktan birçok kimse bu uğurda çalışmalar yapmakla kendilerini sorumlu hissetmişlerdir. ${ }^{101}$

Başkent Kurtuba'da II. Hakem'in kütüphanesinden başka çok değerli şahsi kütüphaneler de bulunuyordu. Kurtuba'da saray kütüphanesinden sonra en büyük kütüphanelerden birisi İbn Futays ailesine aitti. Daha sonra bu kütüphanenin içerisindeki binlerce kitap iç karışıklıklar sırasında kırk bin Kâsımî dinarına satılmıştır. ${ }^{102}$ Ayrıca daha önce adı geçen Aişe bnt. Ahmed eKurtubî'nin (ö. 400/1009) ise Kurtuba'daki en gözde kütüphanelerinden birine sahip olduğu bilinmektedir. ${ }^{103}$

Hiç şüphesiz kütüphaneler ve kitap çarşıları sadece başkent Kurtuba'da değildi. Endülüs'ün muhtelif bölgelerinde de birçok kütüphane ve sahaf bulunmaktaydı. Ancak bunlar Kurtuba'dakiler ile zenginlik ve çeşitlilik yönünden asla yarışamazdı. İnsanlar arasında Kurtuba'da bir şarkıcı ölse, çalgı aletleri İşbiliye'de satılır; buna karşııı İşbiliye'de bir âlim ölse, kitapları hemen Kurtuba'da müşteri buluverirdi sözü darb-ı mesel haline gelmişti. ${ }^{104}$

\footnotetext{
101 Sâid el-Endelüsî, Kitâbu tabakâti'l-ümem, s. 66.

102 İbn-i Beşkuvâl, es-Sıla, II, 468; Özdemir, Endülüs Müslümanları (Kültür ve Medeniyet), Ankara 2013, s. 159.

103 İbn-i Beşkuvâl, es-Sıla, III, 992-993; Özdemir, Endülüs Müslümanları (Kültür ve Medeniyet), s. 159.

104 Makkarî, Nefh, I, 155.
} 
II. Hakem dönemi, erkekler kadar kadınların da ilimle meşgul oldukları bir dönem olmuştur. ${ }^{105} \mathrm{Bu}$ dönemde Endülüs'te ilme merak duyan ve bu konuda ciddi gayretleri ile şöhret bulmuş olan hanımlara da rastlamak mümkündür. ${ }^{106}$ II. Hakem'in kütüphanesinde çalışanlar listesinde daha önceden isimlerini zikrettiğimiz Lübnâ (ö. 374/984) ve Fâtıma bnt. Zekeriyyâ b. Abdullâh (ö. 417/1026) gibi hanımlar bu dönemde şiir ve nesir türü yazılar yazma, hitabet ve hesap ilimlerinde uzmanlaşmıştı. ${ }^{107}$ Yine bu dönemde Safiyye bnt. Abdillâh er-Reyyî (ö. 387/997), Aişe bnt. Ahmed el-Kurtubî (ö. 400/1009), II. Hakem'in babası III. Abdurrahmân'ın cariyesi Râziye (ö. 423/1032) ve Hatîce bnt. Ca'fer et-Temîmî ve gibi bayanlar kendilerini özellikle şiirde ve hitabette yetiştirmişlerdi. ${ }^{108}$ Kuvvetle muhtemel bu hanımlardan bazıları ilimle meşguliyetleri sebebiyle evlenememişlerdi. ${ }^{109}$ Aynı zamanda kitap istinsah etme, ciltleme ve süsleme konularında oldukça mahir olan bu hanımlar, Endülüs'te yaşanan ilmi canlılığa katkıda bulunmaktaydılar. ${ }^{110}$

II. Hakem'in eğitim-ögretim faaliyetlerinin toplumda yaygınlık kazanabilmesi adına gerçekleştirdiği en önemli icraat, fakir ve yetim çocukların ücretsiz eğitim alabilecekleri kurumlar açmasıydı. Onun talimatıyla 356 (967) yılında Kurtuba camiinin batı tarafında daru's-sadaka adı verilen fakir ve kimsesiz çocukların Kur'an'ı Kerimi öğrenebilecekleri ve sarf, nahiv, hadis gibi dersler alabilecekleri bir okul açıldı. Öğrencilerden ücret alınmadan eğitim verilen bu kurumda görevli hocaların maaşları II. Hakem'in hususi hazinesinden karşılanmaktaydı. Daha sonraki süreç içerisinde Kurtuba ve çevresindeki çocukların ücretsiz eğitim gördüğü bu okulların sayısı hızla arttı. Kurtuba camisinin etrafında üç, diğer mahallelerde yirmi dört olmak üzere toplamda yirmi yedi adet bu türden okul açılmıştır. Bu okullar hakkında en detaylı bilgileri aktaran İbn İzârî (ö. 712/1312'den sonra), II. Hakem'in ön ayak olduğu bu uygulamayı onun gerçekleştirdiği en hayırlı işlerden biri olarak nitelemektedir. ${ }^{111}$ İbn

\footnotetext{
105 Makkarî, Nefhu't-tîb, IV, 166.

106 Ziyâ Paşa Endülüs Tarihi (nşr. Yasemin Ödük, Kâzım Masumi, Fatma Şahin), I-IV, İstanbul 2007, I, 120.

107 İbn Beşkuvâl, es-Sıla, III, 992, 994.

108 İbn Beşkuvâl, es-Sıla, III, 992-994,

109 İbn Beşkuvâl, es-Sıla, III, 993-994,

110 Na'naî, Târîhu'd-devleti'l-Emeviyye, s. 410.

111 Ahmed b. Muhammed b. İzârî, el-Beyânu'l-Muğrib fi ihtisâri'l-ahbâri mulûki'lEndelüs ve'l-Mağrib (thk. Beşşar Avvad Ma'ruf, Mahmud Beşşar Avvad), I-IV, Tunus 2013, II, 226; Muhammed Abdülhamîd İsâ, Târîhu't-ta'lîm fi'l-Endelüs, Kahire 1982, s. 207-208; Ebû Sâlih, "Cühûdü'l-Hakem”, VI, 32-33.
} 
Hayyân'ın (ö. 469/1076) vermiş olduğu bilgiye göre II. Hakem, vefatından kısa bir süre öncesine tesadüf eden 364 yılı Cemâziyelevvel ayında (Ocak-Şubat 975) Kurtuba çarşısında kendisine ait "Serrâcîn" dükkânlarının gelirlerini bu okullarda ders veren hocaların maaşlarının karşılanması için tahsis etti. ${ }^{112}$ Böylece o, başlatmış olduğu bu uygulamanın devamlılığını sağlamak adına önemli bir adım atmış oldu.

İnsanların ilim talep etmelerini sürekli teşvik eden ve birçok kimsenin çocuğunun ücretsiz eğitim almasına olanak sağlayan Halife II. Hakem, haklı bir şekilde şâirlerin şiirinde övgüye mazhar olmuştur. Endülüslü şâir Ebû Abdullâh Muhammed b. Şuhays'ın şiirinde bunu net bir şekilde görmek mümkündür.

Ulu camiinin etrafında yetimler için taçlandırılmış okullar mevuttur,

Eğer Kur'an sûrelerine konuşma imkânı verilseydi,

Ey sûreleri okuyan ve kavrayanların hayırlısı diye seni çağırırlardı. ${ }^{113}$

Hollandalı şarkiyatçı Dozy, Endülüs Emevileri'ne ilmî anlamda en parlak devrini yaşatan II. Hakem dönemini değerlendirirken haklı olarak pek çok övgü cümlelerine yer vermektedir. Ona göre II. Hakem gibi münevver bir sultanın kanatları altında Endülüs'te ilmin her alanında büyük gelişmeler yaşanmıştır. Bu dönemde pek çok okulun açıldığına dikkat çeken Dozy, bu hususta Müslümanların idaresi altında bulunan Endülüs ile Hıristiyanların idaresi altında bulunan Avrupa'yı mukayese eder. Bu dönemde Hıristiyanların idaresi altında bulunan Avrupa'da ruhban sınıfına mensup olmayan pek çok insan okuma yazma bilmezken, Endülüs'te neredeyse herkesin okuryazar olduğuna dikkat çeker. Bu durumun ortaya çıkmasında fakir ve kimsesiz çocukların ücretsiz eğitim almalarını sağlamak için II. Hakem'in açmış olduğu okulların önemini vurgular. Bu okullarda ders veren hocaların maaşlarının bizzat II. Hakem'in özel hazinesinden karşılandığını belirtir. ${ }^{114}$

İspanyol araştırmacı Modesto Lafuente'nin, II. Hakem döneminde yaşanan ilmî gelişmelerle ilgili yaptığı değerlendirmeler tam bir hayranlık ifade eder. II. Hakem'in babası III. Abdurrahmân dönemini azamet ve görkem dönemi olarak nitelerken, II. Hakem dönemini ise, edebiyat ve medeniyet dönemi olarak tanımlar. Arap kaynakların övgüyle bahsettikleri aydınlanmacı Halife

\footnotetext{
112 İbn Hayyân, el-Muktebes, s. 207; İbn İzârî, el-Beyânu'l-Muğrib, II, 237; Ebû Sâlih, "Cühûdü'l-Hakem", VI, 33.

113 İbn İzârî, el-Beyânu'l-Muğrib, II, 226.

114 Dozy, Spanish Islam, s. 455; a.mlf, el-Müslimûn fî Endelüs, II, 67.
} 
II. Hakem'in yapmış olduğu güzel icraatları zikretmekten sırf Hristiyan olmadığı için geri kalınamayacağını vurgular. Aksi halde bunun büyük bir haksızlık olacağına dikkat çeker. Ona göre Octavius'un Roma dönemi İspanya'sında tesis ettiği sulhu II. Hakem, Arap İspanya'sında tesis etmiştir. II. Hakem, savaş ve zaferden anlamadığı için değil, aksine Octavius'un yaptığı gibi vicdanının sesine kulak verdiği için kitapları silah depolarına, üniversitelerin taçlarını kanlı savaşların taçlarına tercih etmiştir. II. Hakem ile birlikte İspanya'da Augustos asrı bin sene sonra yeniden diriltilmiştir. Onun döneminde Kurtuba sarayı büyük bir akademiye dönüştürülmüştür. Bu akademiden birçok zeki ve kabiliyetli bilgin yetişmiştir. Büyük çaba ve harcamalar neticesinde 400.000 ila 600.000 cilt kitabın bir araya getirildiği muazzam kütüphane, şüphesiz takdire şayan bir gayretin ve sabrın göstergesidir. Döneminde herkesi barış içerisinde yaşamaktan memnun kaldığı bu meşhur hükümdar tam bir edebiyat aşığıdır. Endülüs'te ondan önce medenîleşme tohumu ekilmişti. Onun döneminde artık ekilen tohum büyümüş, bol yağmurların ve güneş ışınlarının ardından bir fidan olarak filizlenmişti. ${ }^{115}$

\section{Sonuç}

Çocuk yaşta veliaht tayin edilen II. Hakem, babası III. Abdurrahmân tarafından özel olarak yetiştirilmiş ve İslamî ilimlerde dönemin önde gelen âlimlerinden dersler almıştır. İlerleyen yıllarda daha fazla ilgi duyduğu fıkıh, ensâb ve tarih ilimlerinde uzmanlaşmıştır. Babası III. Abdurrahmân'ın uzun süre hayatta kalması sebebiyle çok geç yaşta halife olan ve bu uzun süreç içerisinde ilimle meşguliyetini daha da artıran II. Hakem, okuduğu kitaplara kendi el yazısıyla ilave ettiği şerhlerle dönemindeki ve kendinden sonraki âlimlere kaynaklık etmiştir. Hatta onun, Ensâbu't-tâlibiyyîne ve'l-aleviyyîne'lkâdimîne ilâ'l-Mağrib isimli Endülüs'e gelen Ali evladının neseplerini inceleyen ve diğeri ise İspanya tarihi hakkında olmak üzere iki eser telif ettiği bildirilmektedir. Halife olduktan sonra ilmî alandaki faaliyetlerini daha da yoğunlaştıran II. Hakem, bundan sonraki süreç içerisinde kendisiyle birlikte ülkesinin ve halkın bu alandaki seviyesini artırmak adına elinden gelen bütün gayreti ortaya koymuştur.

Babası III. Abdurrahmân'dan siyasî ve askerî bakımdan sükun ve istikrar sağlanmış bir iktidar devralan II. Hakem dönemi ilmî anlamda en parlak devrin yaşandığı bir dönem olmuştur. İslamî ilimlerde ve müspet bilimlerde 115 İnân, Devletül-İslâm, I, 508-509; Özdemir, Endülüs Müslümanları (Siyasî Tarih), s.
145. 
faaliyet gösteren âlimlere ayırım yapmaksızın kucak açması ve teşvikte bulunması, Endülüs Emevîleri'nin başkenti Kurtuba'nın kısa zamanda canlı bir ilim merkezine dönüşmesini sağlamıştır. Onun teşvikleri ve sağladığı imkanlar sayesinde pek çok yeni kitap telif edilmiştir. Kaynaklarda "kitap kurdu" ve "kitapların dar geldiği bir kütüphaneye" sahip hükümdar olarak tanımlanan II. Hakem'in Kahire, Dımaşk, Bağdat, Mekke, Medine ve Kayrevan gibi önemli merkezlerde kitap toplamak üzere görevlendirdiği özel kimseler bulunmaktaydı. Doğu'da telif edilen kitaplar, onun ilgi ve gayretleri neticesinde piyasaya çıkmadan önce onun kütüphanesine gelirdi. Medinetüzzehrâ saray kütüphanesinde 400.000'e yakın kitap bulunmaktaydı ve bu kitapların isimlerini gösteren ellişer sayfadan oluşan kataloglar kırk dört ciltten oluşmaktaydı. Onun ilme düşkünlüğü ve kitap toplama merakının halk üzerinde meydana getirdiği etki sonucunda Kurtuba önemli bir kitap satış merkezi haline gelmişti. Eğitim alanında fakir ve kimsesiz çocuklara ücretsiz eğitim vermek üzere kurduğu okulla, Kurtuba'da bu türden yirmi yedi okulun açılmasına öncülük etmişti. Onun bu uygulaması, Avrupa'da çok az kimsenin okuma yazma bildiği bu dönemde, ülkesinde okur-yazarlık oranında ciddi bir artışın meydana gelmesini sağlamıştır. Bununla birlikte II. Hakem'den sonra iktidara gelen idarecilerin başta Medinetüzzehrâ saray kütüphanesi olmak üzere kütüphanelerdeki özellikle felsefe içerikli kitapların yakıımasını emretmeleri, onun zamanında yaşanan ilmî canlılı̆ın kısa zamanda sona ermesine neden olmuştur. 


\section{Kaynakça}

Ahatlı, Erdinç, "Yahyâ b. Maîn”, DIA, XXXXIII (İstanbul 2013), s. 256-257.

Algül, Hüseyin, İslam Tarihi, I-IV, İstanbul 1997.

Aykaç, Mehmet, "Arîb b. Sa'd”, DIA, III (İstanbul 1991) s. 359-360.

Bâ'yûn, Sühâ, İshâmu'l-ulemâi'l-müslimîn fi'l-ulûmi fî'l-Endelüs, Beyrut 2008.

Bertrand, Louis, İspanya Tarihi (trc. Galip Kemali Söylemezoğlu-Nurullah Ataç), İstanbul 1940.

Çavuşoğlu, Ali Hakan, "Utbî, Muhammed b. Ahmed”, DIAA, XLII (İstanbul 2012), s. 237-239.

Çiftçi, Faruk, Endülüs'te Hilafet Dönemi Edebî Çevresi (Yayımlanmamış Doktora Tezi), Atatürk Üniversitesi Sosyal Bilimler Enstitüsü, Erzurum 1999.

ed-Dabbî, Ebû Ca'fer Ahmed b. Yahyâ b. Ahmed b. Amîre (ö. 599/1203), Bugyetü'l-mültemis fî târîhi ricâli ehli'l-Endelüs (nşr. İbrâhim elEbyârî), I-II, Kahire-Beyrut 1989.

Dozy, Reinhart Pieter Anne, Histoire des Musulmans d'Espagne 'Spanish Islam' (İngilizce trc. F. Griffin Stokes), London 1972. el-Müslimûn fî Endelüs (Arapça trc. Hasan Habeşî), I-III, Kahire 1994

Düveydâr, Hüseyin Yûsuf, el-Mucteme'u el-Endelüsî fî'l-'asrı'l-Ümevî (138/755-422/1030), İskenderiye 1414/1994.

Ebû Sâlih, Vâil, 'Cuhûdu'l-Hakem el-Mustansır fî tetavvuri'l-hareketi'l-'ilmiyye fîl-Endelüs", Mecelle Dirâsât Endelüsiyye, VI, Tunus, 1411/1991.

Ebü'l-Fidâ, Melikü'l-Müeyyed İmâdüddîn İsmâîl b. Alî b. Mahmûd el-Eyyûbî Ebü'l-Fidâ (ö. 732/1331), el-Muhtasar fî-ahbâri'l-beşer (nşr. Matbaatu'l Hüseyniyye el-Mısriyye), I-IV, Kahire 1286/1869.

Elmalı, Hüseyin, "Kâlî”, DIA, XXIV (İstanbul 2001), s. 259-260.

Görmez, Mehmet, "Kâsım b. Esbağ”, DIA, XXIV (İstanbul 2001), s. 540-541.

Hasan İbrahim Hasan, Siyasi-Dînî-Kültürel-Sosyal İslâm Tarihi (trc. İsmail Yiğit-Sadrettin Gümüş), I-VI, İstanbul 1992.

el-Humeydî, Ebû Abdillâh Muhammed b. Ebî Nasr Fütûh (Fettûh) b. Abdillâh (ö. 488/1095), Cezvetü'l-muktebis fî zikri vülâti'l (fî târîhi ulemâi)Endelüs (nşr. Muhammed Beşşâr Avvâd), Tûnus 2008.

el-Huşenî, Ebû Abdillâh Muhammed b. Hâris b. Esed el-Kayrevânî (ö. 361/971), Kudâtu Kurtuba ve ulemâi Ifrikiyye (thk. Seyyid İzzet Attâr), Kahire 1372/1953.

İbn Asâkir, Ali b. Hasan (ö. 571/1176), Târîhu medîneti Dımaşk (nşr. Ömer b. Garâme el-Amrî), I-LXXX, Beyrut 1415-1421/1995-2001. 
İbn Beşkuvâl, Ebü'l-Kâsım Halef b. Abdülmelik el-Endelüsî (ö. 578/1183), esSıla (nşr. İbrâhim el-Ebyârî), I-III, Kahire 1990.

İbn Cülcül, Ebû Dâvûd Süleymân b. Hassân (ö. 384/994), Tabakâtu'l-etıbbâ ve'l-hukemâ (thk. Fuâd Seyyid), Beyrut 1985.

İbn Ebî Usaybia, Ahmed b. el-Kâsım (ö. 668/1269), Uyûnu'l-enbâ' fî tabakâti'letibbâ' (thk. Nizâr Rızâ), Beyrut 1965.

İbn Ferhûn, Ebü'l-Vefâ (Ebû İshâk) Burhânüddîn İbrâhîm b. Alî b. Muhammed el-Ceyyânî el-Medenî, el-Mâlikî (ö. 799/1397), ed-Dîbâcu'l-müzehheb fî ma'rifeti âyâni ulemâi'l-mezheb (nşr. Muhammed el-Ahmedî Ebu'nnûr), I-II, Kahire 1972.

İbn Haldûn, Ebû Zeyd Abdurrahmân b. Muhammed (ö. 808/1406), Kitâbu'l'Íber ve divânül'-mübtede' ve'I-haber, (nşr. Halîl Şehâde), I-VII Beyrut 2001.

İbn Hayyân, Ebû Mervân Hayyân Halef b. Hüseyn b. Muhammed b. Hayyân el-Kurtubî el-Endelüsî (ö. 469/1076), el-Muktebes min enbâi ehli'lEndelüs (nşr. Abdurrahmân Ali el-Haccî), Beyrut 1965.

İbn Hazm, Ebû Muhammed Alî b. Ahmed b. Saîd el-Endelüsî el-Kurtubî (ö. 456/1064), Cemheretu ensâbi'l-'Arab (nşr. Lêvı-Provençal), Mısır 1948.

İbn İzârî, Ahmed b. Muhammed, (ö. 712/1312'den sonra), el-Beyânu'l-Muğrib fi ihtisâri'l-ahbâri mulûki'l-Endelüs ve'l-Mağrib (thk. Beşşar Avvad Ma'ruf, Mahmud Beşşar Avvad), I-IV, Tunus 2013.

İbn Kesîr, Ebü'l-Fidâ' İmâdüddîn İsmâîl b. Ömer (ö. 774/1373), el-Bidâye ve'nnihâye (nşr. Abdullah b. Abdülmuhsîn et-Türkî), I-XXI, Riyad 1419/1998.

İbn Saîd el-Mağribî, Ebü'l-Hasen Nûruddîn Alî b. Mûsâ b. Muhammed b. Abdilmelîk (ö. 685/1286), el-Muğrib fî hule'I-Mağrib (nşr. Şevkî Dayf), I-II, Kahire 1953-1955.

İbnü'l-Ebbâr, Ebû Abdillâh Muhammed b. Abdillâh b. Ebî Bekr b. Abdîllah b. Abdurrahmân b. Ahmed b. Ebî Bekr el-Kudaî (ö. 658/1260), etTekmile li kitâbi's-sıla (thk. Abdûsselâm Mihrâs), I-IV, Beyrut 1995. , Kitâbu'I-hulleti's-siyarâ' (nşr. Hüseyin Mû'nis), I-II, Kahire 1963.

İbnü'l-Esîr, Alî b. Muhammed (ö. 630/1233), el-Kâmil fi't-târîh (thk. Ebi'l-Fidâ Abdullah el-Kâdî), I-XI, Beyrut, 1987.

İbnü'l-Faradî, Ebü'l-Velîd Abdullah b. Muhammed b. Yûsuf el-Kurtubî el-Ezdî (ö. 403/1013), Târîhu ulemâi'l-Endelüs (nşr. Beşşâr Avvâd), I-II, Tûnus 2008. 
İbnü'l-Hatîb, Ebû Abdillâh Zü'l-vizâreteyn Lisânüddîn Muhammed b. Abdillâh b. Saîd (ö. 776/1374-75), el-Ihâta fi ahbâri Gırnâta (nşr. Muhammed Abdullah İnân), I-IV, Kahire 1974. , A'mâlu'l-A'lâm fî men bûyi'a kable'l-ihtilâm min mulûki'l-íslâm (nşr. Lêvi-Provençal), Beyrut 1956.

İbnü'l-İmâd, Ebü'l-Felâh Abdülhay b. Ahmed b. Muhammed es-Sâlihî elHanbeli (ö. 1089/1679), Şezerâtu'z-zeheb fî ahbâri men zeheb (nşr. Abdülkâdir el-Arnâût, Muhammed el-Arnâût), I-X, Beyrut 1989.

İbnü'l-Kıftî, Alî b. Yûsuf (ö. 646/1248), Ihbâru'l-ulemâ' bi ahbâri'l-hükemâ' (thk. İbrâhim Şemsüddîn), Beyrut 2005.

İmâmuddîn, S. M., Endülüs Siyasi Târihi (trc. Yusuf Yazar), Ankara 1990.

İnân, Muhammed Abdullâh, Devletu'l-İslâm fi'l-Endelüs, I-II, Kahire $1417 / 1997$.

Kâdî İyâz, İyâz b. Mûsâ b. İyâz, Tertîbu'l-medârik ve takrîbu'l-mesâlik (thk. Sa'îd Ahmed A'râb), I-VIII, Rabat 1403/1982.

el-Kâlî, Ebû Alî İsmâîl b. el-Kâsım b. Ayzûn el-Bağdâdî (ö. 356/967), el-Emâlî (nşr. Dâru'l-kutubi'l-ilmiyye), I-IV, Beyrut ts.

el-Kalkaşendî, Ebü'l-Abbâs Şihâbüddîn Ahmed b. Alî (ö. 821/1418), Subhu’la'şâ fî sınâ'ati'I-inşâ (nşr. Muhammed Abdürresûl İbrâhim), I-XIV, Kahire 1340/1922.

el-Makkarî, Ebû'l-Abbâs Şihâbüddîn Ahmed b. Muhammed b. Ahmed elKureşî et-Tilimsânî el-Fâsî (ö. 1041/1632), Nefhu't-tîb min ğusni'lEndelüsi'r-Râtib (thk. İhsân Abbâs), I-VIII, Beyrut 1988.

el-Merrâküşî, Ebû Abdillâh Muhammed b. Muhammed b. Abdilmelik b. Muhammed b. Saîd el-Evsî el-Ensârî (ö. 703/1303), ez-Zeyl ve'ttekmiletu li-kitâbi'l-vusûl ve's-sıla (nşr.İhsân Abbâs), I-VI, Tunus 2012.

Müellifi Meçhul, Zikru bilâdi'l-Endülüs (nşr. Luis Molina), Madrid 1983.

Na'naî, Abdülmecîd, Târîhu'd-devleti'i-emeviyye fî Endülüs, Beyrut 1986.

Özaydın, Abdülkerim, "Sûlî, Ebû Bekir", DIA, XXXVII (İstanbul 2009), s. 492493.

Özdemir, Mehmet, Endülüs Müslümanları (Siyasi Tarih), Ankara 2016. , Endülüs Müslümanları (Kültür ve Medeniyet), Ankara 2013. , "Hakem II", DIA, XV (İstanbul 1997), s. 173-174.

Özel, Ahmet, "Huşenî, Muhammed b. Hâris", DIA, XVIII (İstanbul 1998), s. 421-422.

Provençal, Lêvi, el-Hadâratü'l-'Arabiyye fî İspanya (Arapça trc. Tâhir Ahmed Mekkî), Kahire 1414/1994. 
, Târîhu Ispanya el-Islâmiyye mine'l-fethi ilâ sükûti'l-hilâfetî'lKurtubiyye (711-1031) (Arapça trc. Ali Abdürraûf el-Bembî ve dğr.), III, Kahire 2002.

Ribera, Julian, el-mektebâtu ve hevâtu'l-kutubi fî Ispânyâ el-Islâmiyye (Arapça trc. Cemâl Muhammed Mihraz), I-II, Kahire 1958.

Sâid el-Endelüsî, Ebü'l-Kâsım Sâid b. Ahmed (ö. 462/1070), Kitâbu tabakâtu'lümem (nşr. P. Louis Cheikho), Beyrut 1912.

Sâmirâî, Halîl İbrâhîm, Târîhu'l-Ârab ve hadâratuhum fi'l- Endelüs, Beyrut 2000.

Stanley, Lane-Poole, The Moors of Spain, London 1888.

es-Süyûtî, Ebü'l-Fazl Celâlüddîn Abdurrahmân b. Ebî Bekr b. Muhammed elHudayrî eş-Şâfiî (ö. 911/1505), Buğyetu'l-vu'ât fî tabakati'l-lugaviyyîn ve'n-nuhât (thk. Muhammed Ebu'l-Fazl İbrâhim), I-II, Beyrut 1399/1979.

Tülücü, Süleyman, "el-Bâri", DIA, V (İstanbul 1992), s. 73-74.

Watt, W. Montgomery-CACHIA, Pierre, Endülüs Tarihi (trc. Cumhur Ersin Adıgüzel, Qiyas Şükürov), İstanbul 2011.

Yaşaroğlu, H. Kamil, "ỉbn Müferric", DiA, XX (İstanbul 1999), s. 215.

Yavuz, Mehmet, "ibn Ferec el-Ceyyânî”, DiA, XIX (İstanbul 1999), s. 491.

Yıldız, Hakkı Dursun, (Redaktör), "Endülüs Emevileri”, Doğuştan Günümüze Büyük Islam Tarihi, I-XV, İstanbul 1992.

ez-Zehebî, Ebû Abdillâh Şemsüddîn Muhammed b. Ahmed (ö. 748/1348), Siyeru a'lâmi'n-nübelâ' (nşr. Şuayb el-Arnâut), I-XXV, Beyrut 19811982.

, Târîhu'l-Islâm ve vefeyâtu'l-meşâhîr ve'l-a'lâm (nşr. Ömer Abdüsselâm Tedmürî), I-LIII, Beyrut 1989.

Düvelül'Islâm (nşr. Hasan İsmâil Merve, Mahmûd el-Arnâût), I-II, Beyrut 1999.

Zevalsiz, Halit, "Zübeydî, Ebû Bekir", DIA, XLIX (İstanbul 2013), s. 519-520.

Ziya Paşa (ö. 1297/1880), Endülüs Tarihi (nşr. Yasemin Ödük, Kâzım Masumi, Fatma Şahin), I-IV, İstanbul 2007.

ez-Zübeydî, Ebû Bekr Muhammed b. el-Hasen b. Abdillâh b. Mezhic (ö. 379/989), Tabakâtu'n-nahviyyîn ve'l-lügaviyyîn (nşr. Muhammed Ebû'l-Fazl İbrâhim), Kahire 1954. 


\section{Hakam II, Caliph of Andalusian Umayyads, as a Scholar and His Contributions to the Scholarly Activities of His Time}

Citation / @-Yılmaz, S.- Erbaş, F. (2017). Hakam II, Caliph of Andalusian Umayyads, as a Scholar and His Contributions to the Scholarly Activities of His Time, Çukurova University Journal of Faculty of Divinity, 17 (1), 157-185.

Abstract- The most brilliant era of the Caliphate of Andalusian Umayyads in terms of scientific activities is under reign of the Hakam II, who is also a scholar and therefore is called "Wise Caliph", made great efforts to increase the scientific activities in his country. The fact that he embraced scholars of his time without making any distinction and provided many possibilities for scholars helped the capital Cordoba to become an important scientific center. At the same time, the imperial library of the Palace of Madinat al Zahra which contained many valuables collections of manuscripts collected from all over the world has become one of the three largest libraries of Islamic world. Schools offering free education to poor children have been opened, resulting in a significant increase in the literacy rate in the country. This article which consists of two parts, will focus in the first part on his scholarship in traditional Islamic sciences, and in the second part on the contributions he made to the scientific activities in Cordoba.

Keywords- The Caliphate of Andalusian Umayyads, Hakam b. Abdurrahman, Madrasah of Cordoba, The Library of the Palace of Madinat al Zahra 